\title{
Phosphogenesis and active phosphorite formation in sediments from the Arabian Sea oxygen minimum zone
}

\author{
S.J. Schenau*, C.P. Slomp, G.J. De Lange \\ Department of Geochemistry, Institute of Earth Sciences, Utrecht University, Budapestlaan 4, 3584 CD Utrecht, Netherlands
}

Received 2 July 1999; accepted 22 June 2000

\begin{abstract}
In this study, porewater chemistry, solid-phase analysis and microscopic observations were combined to evaluate phosphogenesis in three boxcores located within the intensive oxygen minimum zone of the Arabian Sea. Three parameters, namely a decrease of the dissolved phosphate and fluoride concentrations with depth, saturation with respect to carbonate fluorapatite, and the presence of a solid-phase Ca-phosphate mineral, all indicate that phosphogenesis is currently taking place at all three sites. Authigenic apatite precipitation rates vary between 0.076 and $1.04 \mu \mathrm{molP} \mathrm{cm} \mathrm{yr}^{-1}$, and are of the same order of magnitude as reported for other high productivity areas. Precipitation of an intermediate precursor precedes francolite formation in the continental slope sediments on the Karachi Margin. Results of a diagenetic P model indicate that phosphogenesis is induced by high rates of organic matter degradation. Dissolution of fish debris is likely to provide a substantial additional source of phosphate. Redox iron cycling does not influence phosphogenesis in these environments. Model results suggest that sediment mixing is essential in promoting early diagenetic phosphogenesis. The highest rate of francolite formation was observed in a boxcore taken on the Oman Margin, where it contributes to the formation of a Holocene phosphorite deposit. This observation contrasts with previous reports of only old phosphorites in this area. Phosphorites are presently forming on the Oman Margin as a result of: (a) deposition of older, reworked material from the continental shelf, which has undergone an earlier phase of phosphogenesis; (b) a high input of reactive P (fish debris and degradable organic matter); (c) a relatively low sediment accumulation rate; and (d) the absence of winnowing on this location. Holocene phosphorite deposits may be less common on the Oman Margin than in other coastal upwelling areas because of the narrowness of the shelf and the steepness of the slope, which limit the area where phosphorite formation may occur. (C) 2000 Elsevier Science B.V. All rights reserved.
\end{abstract}

Keywords: Phosphogenesis; Phosphorites; Oxygen minimum zone; Arabian Sea; Early diagenesis

\section{Introduction}

Phosphogenesis is the early diagenetic precipitation of francolite, a carbonate fluorapatite mineral (CFA). Authigenic apatite formation is an important sedimentary sink for reactive phosphorus in the oceans (Ruttenberg and Berner, 1993). The major element

\footnotetext{
* Corresponding author.

E-mail addresses: sjoerds@geo.uu.nl (S.J. Schenau), slomp@ geo.uu.nl (C.P. Slomp), gdelange@geo.uu.nl (G.J. De Lange).
}

composition of marine sedimentary apatite displays little variation (e.g. Jarvis et al., 1994), and approaches the simplified formula $\mathrm{Ca}_{10}\left[\left(\mathrm{PO}_{4}\right)_{6-x}\right.$ $\left.\left(\mathrm{CO}_{3}\right)_{x}\right] \mathrm{F}_{2+x}$. In organic-rich sediments, francolite precipitation is usually restricted to the uppermost part of the sediment because the increase of carbonate alkalinity with depth prohibits further formation of apatite (Jahnke et al., 1983; Glenn and Arthur, 1988), and because francolite formation requires fluoride diffusing from the overlying bottom water (Froelich et al., 1983). 
For the evaluation of $\mathrm{P}$ cycling in the oceans, it is important to understand the environmental conditions influencing phosphogenesis. Saturation of the interstitial water with respect to francolite is primarily controlled by the flux of reactive phosphorus transferred to the sediment (e.g. Filippelli and Delaney, 1994). Phosphate production in the porewater may originate from microbial degradation of organic matter (e.g. Froelich et al., 1988; Ruttenberg and Berner, 1993), desorption from iron oxides (e.g. Sundby et al., 1992; Slomp et al., 1998) and dissolution of fish debris (Suess, 1981). A second prerequisite for francolite precipitation is that sedimentary conditions have to permit the build up of phosphate in the porewater. High porosities enhance phosphate diffusion to the bottom water and reduce the capacity to retain reactive $\mathrm{P}$ in the sediment (Van Cappellen and Berner, 1988; Filippelli and Delaney, 1994). Early diagenetic iron cycling has been shown to promote phosphogenesis under oxygenated bottom water conditions (Sundby et al., 1992; Slomp et al., 1996). In addition, redox dependent cycling of phosphate by microorganisms (e.g. Ingall and Jahnke, 1994) and microbial mat communities at the sediment water interface (e.g. Williams and Reimers, 1983; Krajewski et al., 1994) may play an important role in regulating the interstitial phosphate concentrations. Benthic $\mathrm{P}$ regeneration and consequent loss of phosphate to the water column appears to be more extensive under oxygen-depleted bottom water conditions (Ingall and Jahnke, 1994). As a consequence, phosphogenesis is often associated to oxic to suboxic bottom water conditions (Heggie et al., 1990; Ingall et al., 1993; Jarvis et al., 1994).

Coastal upwelling areas are known to have sediments with high authigenic phosphorus contents, defined as phosphorites when containing more than $5 \mathrm{wt} \% \mathrm{P}_{2} \mathrm{O}_{5}$ (e.g. Cook, 1984). These high sedimentary $\mathrm{P}$ concentrations are thought to result from high francolite precipitation rates during early diagenesis and processes of sediment reworking (e.g. redeposition, winnowing; Kolodny, 1981; Froelich et al., 1988). Phosphorites have been found worldwide in numerous geological formations (e.g. Filippelli and Delaney, 1994; Föllmi, 1996; Trappe, 1998), but their recent formation is a relatively rare phenomenon (Jahnke et al., 1983; Thomson et al., 1984; Froelich et al., 1988; Heggie et al., 1990; Schuffert et al., 1994,
1998). In addition to upwelling areas, phosphogenesis has been recognised in sediments of shallow continental margins (Ruttenberg and Berner, 1993; Reimers et al., 1996; Louchouarn et al., 1997), the continental slope underlying low productivity areas (Slomp et al., 1996) and in deep-sea sediments (Lucotte et al., 1994; Filippelli and Delaney, 1996).

The Arabian Sea is characterised by high seasonal productivity (Qasim, 1982), which is caused by monsoonal induced coastal and open-ocean upwelling offshore Oman and Somalia. High vertical fluxes of organic matter, in combination with sluggish ventilation owing to the semi-enclosed configuration of the Arabian Basin, result in an intensive oxygen minimum zone (OMZ) between 150 and $1250 \mathrm{~m}$ water depth, with oxygen concentrations $<2 \mu \mathrm{M}$ (e.g. Van Bennekom and Hiehle, 1994). Ancient phosphorite deposits, dating from the Miocene till Early Pleistocene, have been found in ODP cores recovered from the Oman Margin (Rao and Lamboy, 1995). Until now, recent phosphorite formation in this area has never been reported. This is surprising, as the environmental conditions for the Oman upwelling area are in many aspects similar to that of Peru-Chile and Namibia.

In this study, we investigate phosphogenesis in three boxcores from the Arabian Sea located within oxygen-depleted bottom waters, one recovered from the sediments underlying the Oman upwelling system, and two from the Pakistan Margin. We apply a diagenetic model for sedimentary P cycling developed by Slomp et al. (1996) to porewater and solid-phase P profiles to gain a better insight into the processes controlling phosphogenesis in these environments. In contrast to previous reports, we present evidence for Holocene phosphorite formation on the Oman Margin.

\section{Material and methods}

\subsection{Sediment sampling and core description}

During the Netherlands Indian Ocean program (1992) three boxcores were collected for this study: $\mathrm{BC} 484$ was recovered from the Oman Margin from a depth of $527 \mathrm{~m}, \mathrm{BC} 451$ and BC455 from the Karachi Margin, from depths of 495 and $1005 \mathrm{~m}$, respectively (Table 1; Fig. 1). All three boxcores are located within 
Table 1

Position, water depth, sedimentation rate $(\omega)$, organic carbon concentration in the top $\mathrm{cm}$, oxygen concentration and bottom water temperature of the sampled boxcores

\begin{tabular}{llllllrr}
\hline Site & $\begin{array}{l}\text { Latitude } \\
(\mathrm{N})\end{array}$ & $\begin{array}{l}\text { Longitude } \\
(\mathrm{E})\end{array}$ & $\begin{array}{l}\text { Water depth } \\
(\mathrm{m})\end{array}$ & $\begin{array}{l}\omega \\
\left(\mathrm{cm} \mathrm{kyr}{ }^{-1}\right)\end{array}$ & $\begin{array}{l}\mathrm{C}_{\text {org }} \text { top cm } \\
(\mathrm{wt} \%)\end{array}$ & $\begin{array}{l}\mathrm{T} \text { bottom } \\
\left(\mathrm{C}^{\circ}\right)\end{array}$ & $\begin{array}{l}{\left[\mathrm{O}_{2}\right] \text { bottom water }} \\
(\mu \mathrm{M})\end{array}$ \\
\hline BC484 & $19^{\circ} 30.0^{\prime}$ & $58^{\circ} 25.8^{\prime}$ & 527 & 5.6 & 2.24 & 12.3 & $<2$ \\
$\mathrm{TC} 484$ & $19^{\circ} 29.8^{\prime}$ & $58^{\circ} 25.7^{\prime}$ & 516 & - & - & - & - \\
$\mathrm{BC} 451$ & $23^{\circ} 41.4^{\prime}$ & $66^{\circ} 02.9^{\prime}$ & 495 & 28 & 4.37 & 12.6 & $<2$ \\
BC455 & $23^{\circ} 33.0^{\prime}$ & $65^{\circ} 57.4^{\prime}$ & 1005 & 16 & 3.43 & 8.7 & $<2$ \\
\hline
\end{tabular}

the $\mathrm{OMZ}$ and underlie an area of high primary productivity. In addition, a tripcore (TC484), taken on nearly the same location as BC484 (at a distance of $\pm 4 \mathrm{~km}$ ), was studied. Bottom water oxygen (BWO) concentrations were obtained from nearby conductivity temperature depth (CTD) stations. ${ }^{14} \mathrm{C}$ accelerator mass spectrometry (AMS) dating was performed on handpicked non-coated foraminifers (Globorotalia menardii), coated foraminifers and phosphorite pellets. AMS ${ }^{14} \mathrm{C}$ ages were calibrated according to Stuiver et al. (1998) and corrected for a reservoir age of $400 \mathrm{yr}$ (Bard et al., 1990). Sedimentation rates, $\omega$, (Table 1) were calculated from the ages of non-coated foraminifers.

\subsection{Porewater analysis}

Porewater extractions were started on board within
$24 \mathrm{~h}$ of core collection according to shipboard routine (De Lange, 1992a). The boxcores were vertically sluiced into a glovebox, which was kept under lowoxygen conditions $\left(\mathrm{O}_{2}<0.0005 \%\right)$ and at in situ bottom water temperature. Under a nitrogen pressure of up to 7 bar, porewaters were extracted in Reeburghtype squeezers. The shipboard $\mathrm{pH}$ measurements and nutrient analyses were performed within $12 \mathrm{~h}$ after the extraction of the porewaters. Alkalinity was calculated after titration using the Gran plot method (Gieskes, 1973). Phosphate and ammonium were measured on a TRAACS 800 auto analyser, according to automated methods of Strickland and Parsons (1968) and Solarzano (1969), respectively. All analyses were performed in duplicate. Porewater fluoride concentrations were measured with an ionspecific electrode. Relative errors were smaller than $2 \%$.

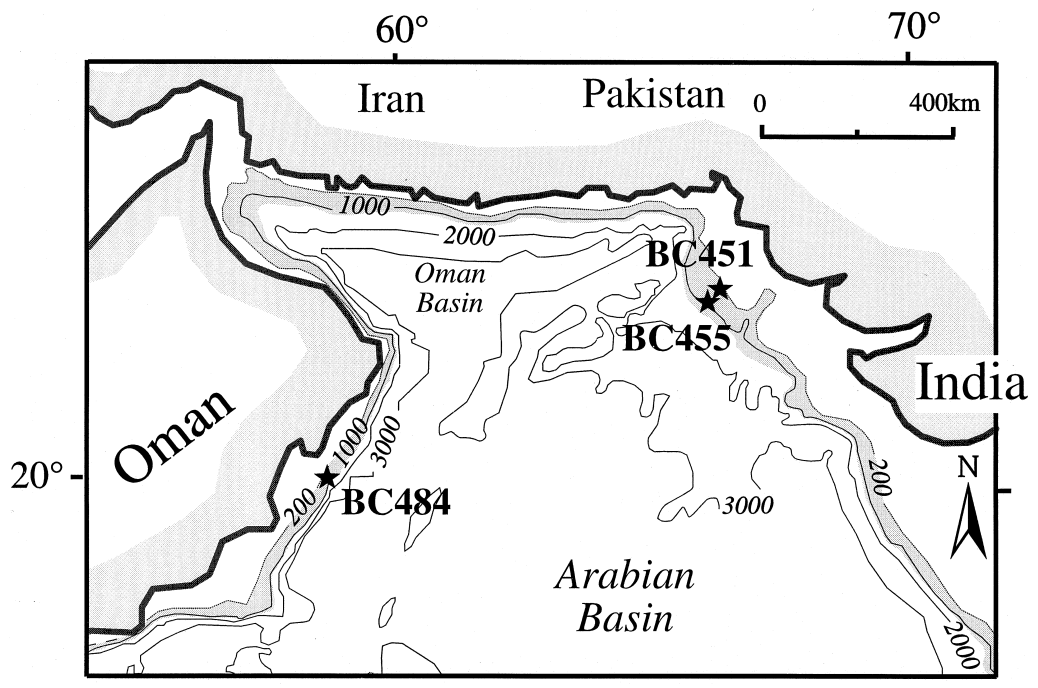

Fig. 1. Positions of the boxcore sample sites. The area where the present-day OMZ impinges on the continental slope is shaded. 
Table 2

The $\mathrm{P}$ sequential extraction scheme and extracted fractions

\begin{tabular}{|c|c|c|c|}
\hline Step & Extractant & $P$ phase extracted & Reference \\
\hline 1 & 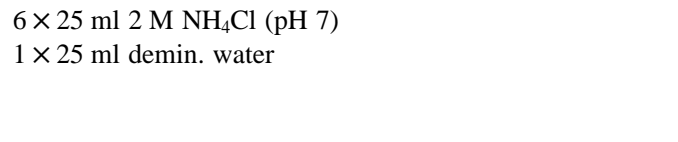 & $\begin{array}{l}\mathrm{P}_{\mathrm{NH} 4 \mathrm{Cl}} \\
\text { Exchangeable or loosely sorbed } \mathrm{P} \\
\text { Carbonate associated } \mathrm{P} \\
\text { Fish debris }\end{array}$ & De Lange, $1992 b$ \\
\hline 2 & $\begin{array}{l}2 \times 25 \mathrm{ml} 1 \mathrm{M} \mathrm{Na}-\text { acetate, buffered to } \mathrm{pH} 6 \text { with acetic acid } \\
1 \times 25 \mathrm{ml} 2 \mathrm{M} \mathrm{NH}_{4} \mathrm{Cl}(\mathrm{pH} 7) \\
1 \times 25 \mathrm{ml} \mathrm{demin} . \text { water }\end{array}$ & Residual carbonate associated $\mathrm{P}$ & - \\
\hline 3 & $\begin{array}{l}1 \times 25 \mathrm{ml} 0.15 \mathrm{M} \mathrm{Na} \text {-citrate, } 0.5 \mathrm{M} \mathrm{NaCO}_{3}(\mathrm{pH} 7.6) \text {, and } \\
1.125 \mathrm{~g} \mathrm{Na} \text {-dithionite } \\
1 \times 25 \mathrm{ml} 2 \mathrm{M} \mathrm{NH}_{4} \mathrm{Cl}(\mathrm{pH} 7) \\
1 \times 25 \mathrm{ml} \mathrm{demin} . \text { water }\end{array}$ & $\begin{array}{l}\mathrm{P}_{\mathrm{Pfe}} \\
\text { Easily reducible or reactive iron bound } \mathrm{P}\end{array}$ & Ruttenberg, 1992 \\
\hline 4 & $\begin{array}{l}2 \times 25 \mathrm{ml} 1 \mathrm{M} \mathrm{Na}-\text { acetate buffered to } \mathrm{pH} 4 \text { with acetic acid } \\
1 \times 25 \mathrm{ml} 2 \mathrm{M} \mathrm{NH}_{4} \mathrm{Cl}(\mathrm{pH} 7) \\
1 \times 25 \mathrm{ml} \text { demin. water }\end{array}$ & $\begin{array}{l}\mathrm{P}_{\text {cfa }} \\
\text { Carbonate fluorapatite (CFA) }\end{array}$ & Ruttenberg, 1992 \\
\hline 5 & $\begin{array}{l}1 \times 25 \mathrm{ml} 1 \mathrm{M} \mathrm{HCl} \\
1 \times 25 \mathrm{ml} \mathrm{demin} . \text { water }\end{array}$ & $\begin{array}{l}\mathrm{P}_{\text {det }} \\
\text { Detrital apatite }\end{array}$ & Ruttenberg, 1992 \\
\hline 6 & $20 \mathrm{ml} \mathrm{HF} / \mathrm{HNO}_{3} / \mathrm{HClO}_{4}$ & $\begin{array}{l}\mathrm{P}_{\text {res }} \\
\mathrm{P} \text { adsorbed to clay minerals } \\
\text { Organic } \mathrm{P}\end{array}$ & Lord, 1982 \\
\hline
\end{tabular}

\subsection{Solid-phase analysis}

The porosity and dry bulk density (DBD) were calculated from the weight loss after drying at $60^{\circ} \mathrm{C}$, assuming a sediment density of $2.65 \mathrm{~g} \mathrm{~cm}^{-3}$. After removal of inorganic carbon with $1 \mathrm{M} \mathrm{HCl}$, the organic carbon $\left(\mathrm{C}_{\mathrm{org}}\right)$ content and total nitrogen content $\left(\mathrm{N}_{\text {tot }}\right)$ were measured with an NA $1500 \mathrm{NCS}$ analyser. Relative errors were smaller than $0.4 \%$. For the determination of total $\mathrm{P}, \mathrm{Ca}, \mathrm{Al}, \mathrm{Ti}$ and $\mathrm{Zr}, 250 \mathrm{mg}$ of the sample was totally digested in $10 \mathrm{ml}$ of a 6.5:2.5:1 mixture of $\mathrm{HClO}_{4}(60 \%), \mathrm{HNO}_{3}(65 \%)$ and $\mathrm{H}_{2} \mathrm{O}$, and $10 \mathrm{ml} \mathrm{HF}(40 \%)$ at $90^{\circ} \mathrm{C}$. After evaporation of the solutions at $190^{\circ} \mathrm{C}$ on a sand bath, the dry residue was dissolved in $50 \mathrm{ml} 1 \mathrm{M} \mathrm{HCl}$. The resulting solutions were analysed with an inductively coupled plasma atomic emission spectrometer (ICP-AES; Perkin-Elmer Optima 3000). All results were checked using international (SO1, SO3) and in-house standards. Relative errors for duplicate measurement were better than 3\%, except for $\mathrm{Zr}$ and $\mathrm{Ti}$ (5\%). Particle sizes were determined on the bulk wet sediment and on carbonate and organic matter free fractions, using a Laser Particle Sizer (Malvern Series 2600).
The distribution of different phosphorus fractions in sediment samples was examined with a six-step sequential extraction scheme, which is an adaptation of the SEDEX method developed by Ruttenberg (1992) with additional steps for selective Ca-carbonate extraction (Table 2). Approximately $250 \mathrm{mg}$ of dried sediment was subsequently washed with (1) $25 \mathrm{ml} 2 \mathrm{M} \mathrm{NH}_{4} \mathrm{Cl}, \mathrm{pH}=7(6 \times)$, (2) $25 \mathrm{ml} \mathrm{Na}$-acetate solution, $\mathrm{pH}=6$, (3) $25 \mathrm{ml}$ citrate dithionite buffer (CDB), $\mathrm{pH}=7.6$, (4) $25 \mathrm{ml}$ Na-acetate solution, $\mathrm{pH}=4$, (5) $25 \mathrm{ml} 1 \mathrm{M} \mathrm{HCl}$ and (6) $20 \mathrm{ml} \mathrm{HF} /$ $\mathrm{HNO}_{3} / \mathrm{HClO}_{4}$ mixture. After extraction steps 2-5 the sediment was rinsed successively with $2 \mathrm{M}$ $\mathrm{NH}_{4} \mathrm{Cl}(\mathrm{pH}=7)$ and demineralised water to prevent readsorption of $\mathrm{HPO}_{4}^{2-}$. The first extraction step differs from the SEDEX method in that $2 \mathrm{M} \mathrm{NH}_{4} \mathrm{Cl}$ is used instead of $1 \mathrm{M} \mathrm{MgCl}_{2}$ to dissolve carbonates prior to the other extraction steps (De Lange, 1992b). This has the advantage that carbonates are dissolved selectively, allowing a differentiation between francolite and more soluble calcium-phosphate minerals (Schenau and De Lange, 2000). A separate sequential extraction consisting of eight times the $2 \mathrm{M} \mathrm{NH}_{4} \mathrm{Cl}$ step was performed for some sediment samples, 
where each extracted solution was analysed separately. The Na-acetate $(\mathrm{pH}=6)$ extraction (step 2) was added to ensure complete carbonate removal, since incomplete dissolution of $\mathrm{Ca}$-carbonates might cause precipitation of gypsum in the subsequent $\mathrm{Na}-$ dithionite extraction (step 3). All extracted solutions were measured for P with ICP-AES. Reproducibility was generally better than 5\%, except for step $3(10 \%)$. The recovery with respect to the total $\mathrm{P}$ concentration was 90,83 and $90 \%$ for $\mathrm{BC} 484, \mathrm{BC} 451$ and $\mathrm{BC} 455$, respectively. Fluoride concentrations in the extracted solutions of BC484 were measured with an ion-specific electrode. For some samples, organic phosphorus $\left(\mathrm{P}_{\text {org }}\right)$ was determined according to the method of Aspila et al. (1976).

Separate sediment samples were sieved into three fractions $(65-150,150-595$ and $>595 \mu \mathrm{m})$. For $\mathrm{BC} 484$, these fractions were weighed and, after total digestion, analysed with ICP-AES. For all boxcore samples fish debris was quantified in the 150$595 \mu \mathrm{m}$ fraction by counting the number of fish fragments in splits (using an Otto microsplitter). Coated foraminifers, dark brownish pellets and fish debris in the top sediment of BC484 were hand picked from the $150-595 \mu \mathrm{m}$ fraction. A few particles were embedded in resin and analysed for $\mathrm{Ca}, \mathrm{P}$ and $\mathrm{F}$ contents using an electron microprobe-scanning electron microscope (JEOL 8600).

\subsection{Description of the model}

A diagenetic model for $\mathrm{P}$ cycling developed by Slomp et al. (1996) was applied to the porewater and sequential extraction results for BC451 and BC455. This steady state model describes the concentration change with depth of porewater phosphate and three forms of solid-phase $\mathrm{P}$, namely organic $\mathrm{P}, \mathrm{Fe}-$ bound $\mathrm{P}$ and authigenic $\mathrm{P}$. As the sequential extraction results for $\mathrm{BC} 484$ are not accurate for all $\mathrm{P}$ phases, and some of the material may have been redeposited (see Sections 3 and 4), the model was not applied to this boxcore. The sediment column is divided into three zones: an oxidised surface zone (I: $0 \leq x \leq$ $L_{1}$ ), a reduced sediment zone with bioturbation (II: $L_{1} \leq x \leq L_{2}$ ), and a reduced sediment zone without bioturbation (III: $x>L_{2}$ ). The processes included in the model are: (1) phosphate release from organic $\mathrm{P}$ due to organic matter degradation (zones I, II, III); (2) reversible sorption of phosphate to iron oxides (zone I); (3) phosphate release from Fe-bound $\mathrm{P}$ due to iron oxide reduction (zones II, III); and (4) authigenic P precipitation (zones II, III). Note that phosphate release from fish debris dissolution is not included in this model. The processes (1)-(4) are described as first-order reactions, with reaction rate constants $k_{\mathrm{g}}, k_{\mathrm{s}}, k_{\mathrm{m}}$ and $k_{\mathrm{a}}$, respectively. The set of differential equations for the one-dimensional distribution of porewater $\mathrm{HPO}_{4}^{2-}$ and the three particulate $\mathrm{P}$ forms was solved analytically assuming continuity in concentrations and fluxes at the boundaries between the three depth zones and appropriate boundary conditions for the system. The porewater equilibrium concentrations for sorption and apatite precipitation are $C_{\mathrm{s}}$ and $C_{\mathrm{a}}$, respectively. The bottom water concentration is $C_{0}$. The asymptotic Fe-bound $\mathrm{P}$ and organic $\mathrm{P}$ concentrations are equal to $M_{\infty}$ and $G_{\infty}$. The molecular $\left(D_{\mathrm{s}}\right)$ and biodiffusion $\left(D_{\mathrm{b}}\right)$ coefficients, sedimentation rate $(\omega)$, reaction rate constants and sediment porosity $(\phi)$ are assumed to be constant with depth in each relevant layer. In addition, the fluxes of organic $\mathrm{P}$ $\left(J_{\mathrm{Gx}=0}\right)$, Fe-bound $\mathrm{P}\left(J_{\mathrm{Mx}=0}\right)$ and "authigenic" $\mathrm{P}\left(J_{\mathrm{ax}=0}\right.$; i.e. the $\mathrm{P}$ fraction associated with fish debris, $\mathrm{Ca}$ carbonates, easily exchangeable $\mathrm{P}$ and resuspended authigenic apatite) from the water column to the sediment are assumed to be constant. Values of $k_{\mathrm{g}}, k_{\mathrm{m}}, k_{\mathrm{a}}$, $J_{\mathrm{Ax}=0}$ and $J_{\mathrm{Gx}=0}$ were varied to fit the model to the experimental data. Variance-weighted sums of squares of the difference between the modelled and experimental values were minimised for all four components, i.e. phosphate, organic $\mathrm{P}, \mathrm{Fe}$-bound $\mathrm{P}$ and authigenic $\mathrm{P}$, simultaneously. Extra weight was assigned to the data points in the upper part of each profile and the whole authigenic $\mathrm{P}$ profile. The other parameters $\left(L_{1}, L_{2}, D_{\mathrm{s}}, D_{\mathrm{b}}, \omega, C_{0}, C_{\mathrm{s}}, C_{\mathrm{a}}, k_{\mathrm{s}}, J_{\mathrm{Mx}=0}\right.$, $M_{\infty}$ and $G_{\infty}$ ) were fixed on the basis of existing data.

\section{Results}

\subsection{Porewater}

The phosphate concentration in $\mathrm{BC} 484$ is characterised by a sharp increase to $75 \mu \mathrm{M}$ just below the sediment surface, followed by a decrease to $20 \mu \mathrm{M}$ at the base of the boxcore (Fig. 2). In BC451 and BC455, the phosphate concentrations are lower, and the 

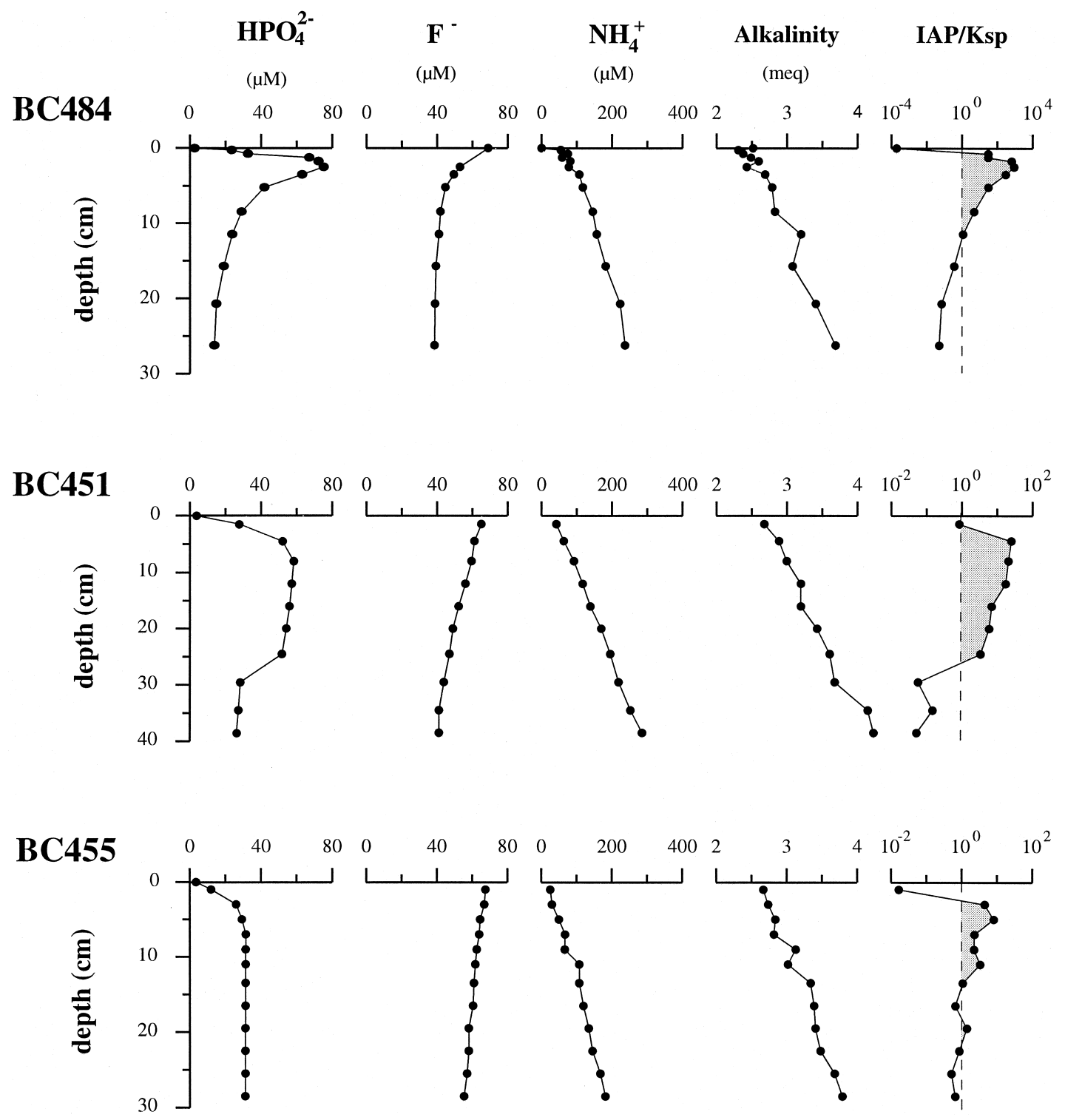

Fig. 2. Porewater profiles for BC484 BC451, BC455: phosphate, fluoride, ammonium and alkalinity. The saturation state with respect to francolite in the porewaters was calculated as IAP (ion activity product) divided by the $K_{\mathrm{sp}}$ (solubility product of francolite). The shaded areas indicate saturation.

decrease of phosphate with depth is less pronounced (BC451) or absent (BC455). Fluoride concentrations decrease with depth in all three boxcores, whereas the ammonium concentrations and alkalinity increase almost linearly with depth (Fig. 2). BWO concentrations for all three boxcores are below the detection limit ( $2 \mu \mathrm{M}$; Table 1$)$.

\subsection{Solid phase}

The total P content is high in the top of BC484 (up to $2.0 \mathrm{wt} \%$ ) (Fig. 3), corresponding to approximately $5 \mathrm{wt} \%$ of $\mathrm{P}_{2} \mathrm{O}_{5}$, which classifies this sediment as a phosphorite. The $\mathrm{P}$ concentration in this core gradually decreases with depth to ca. $4000 \mathrm{ppm}$. 


$\begin{array}{cccccc}\mathbf{P}_{\mathrm{NH} 4 \mathrm{Cl}} & \mathbf{P}_{\mathrm{Fe}} & \mathbf{P}_{\mathrm{CFA}} & \mathbf{P}_{\text {det }} & \mathbf{P}_{\text {res }} & \text { Tot P } \\ (\text { Step 1 + 2) } & (\text { Step 3) } & (\text { Step 4) } & (\text { Step 5) } & \text { (step 6) } & \end{array}$

\section{BC484}

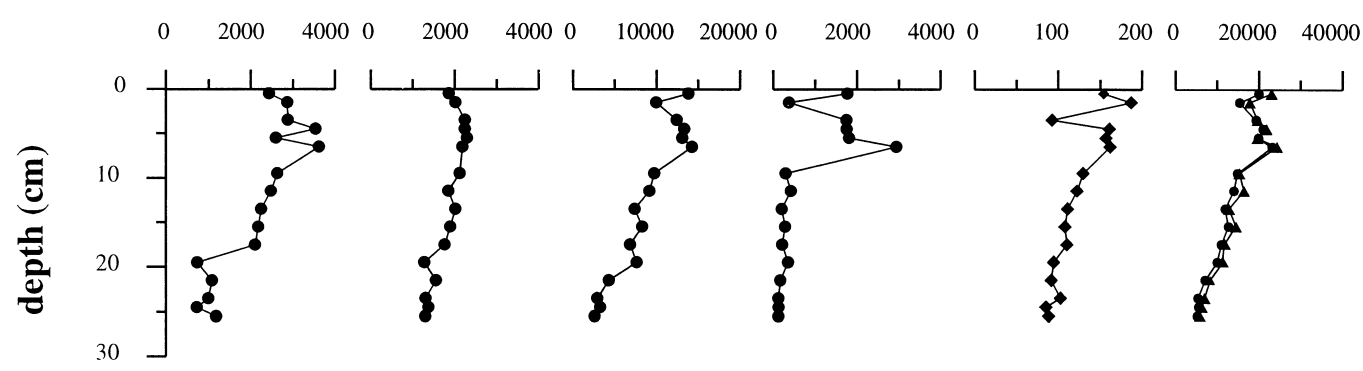

BC451

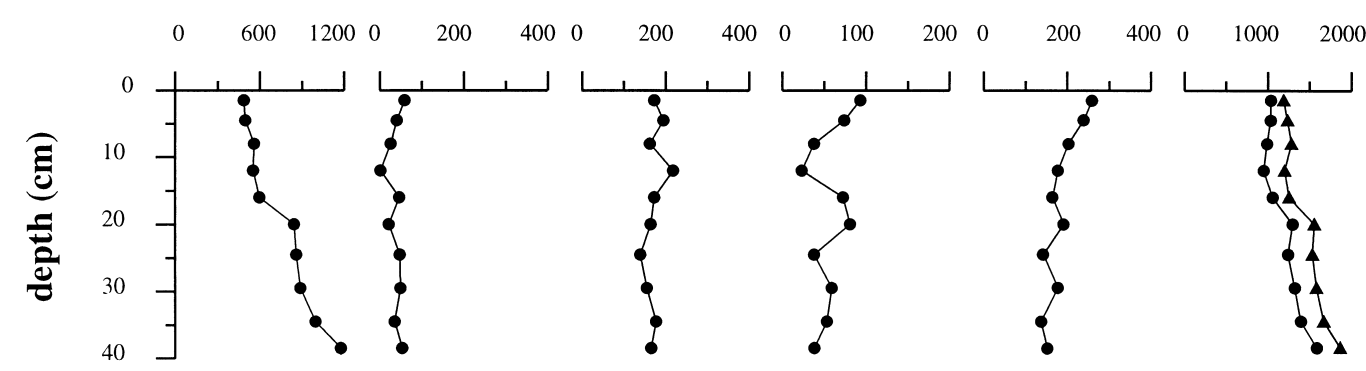

BC455

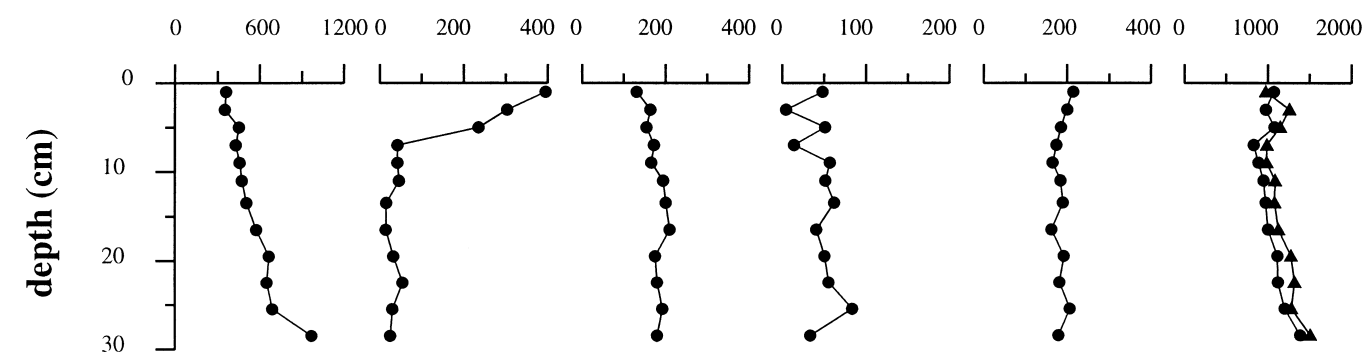

Fig. 3. Profiles of extracted $P$ phases (ppm): $P_{N H 4 C l}$ (steps $\left.1+2\right), P_{F e}$ (step 3), $P_{C F A}$ (step 4), $P_{\text {det }}$ (step 5), $P_{\text {res }}$ (steps $6+7$ ), total $P$, as measured after total destruction $(\boldsymbol{\Lambda})$, and the sum of all extracted $\mathrm{P}$ phases $(\bullet)$. Note the different scales for BC484.

Phosphorus is concentrated in the coarse fraction of the sediment, namely, in concentrations up to $5.5 \mathrm{wt} \%$ in the $150-595 \mu \mathrm{m}$ fraction. Approximately $20 \%$ of the solid-phase $\mathrm{P}$ is present in the fraction smaller than $65 \mu \mathrm{m}$, which constitutes $50 \mathrm{wt} \%$ of the bulk sediment. Total $\mathrm{P}$ contents in $\mathrm{BC} 451$ and $\mathrm{BC} 455$ are much lower (1000-2000 ppm) and increase with sediment depth.

The major $\mathrm{P}$ fraction in $\mathrm{BC} 484$ is extracted in step 4 (authigenic apatite). All P fractions in this core show a decrease of $\mathrm{P}$ with depth (Fig. 3). Probably, francolite is partially dissolving in the other extraction steps in this boxcore. This is confirmed by fluoride analysis of the solutions from step 2 to 5 , which revealed a constant molar $\mathrm{P} / \mathrm{F}$ ratio of 2.4. In $\mathrm{BC} 451$ and $\mathrm{BC} 455$, the $\mathrm{P}$ fraction responsible for the increase with depth of total solid-phase $\mathrm{P}$ was extracted during steps 1 and 2 (Fig. 3). The $\mathrm{P}_{\mathrm{Fe}}$ fraction in $\mathrm{BC} 451$ is low ( $\sim 40 \mathrm{ppm}$ ). In the top of $\mathrm{BC} 455, \mathrm{P}_{\mathrm{Fe}}$ is enriched up to $400 \mathrm{ppm}$. The $\mathrm{P}_{\mathrm{CFA}}$ and $\mathrm{P}_{\text {det }}$ fractions are nearly constant with depth in both BC451 and BC455. The residual $\mathrm{P}$ fraction $\left(\mathrm{P}_{\text {res }}\right)$ decreases with depth in the top $10 \mathrm{~cm}$ of the sediment. The good correspondence between $\mathrm{P}_{\text {org }}$ (as determined with the Aspila method, 

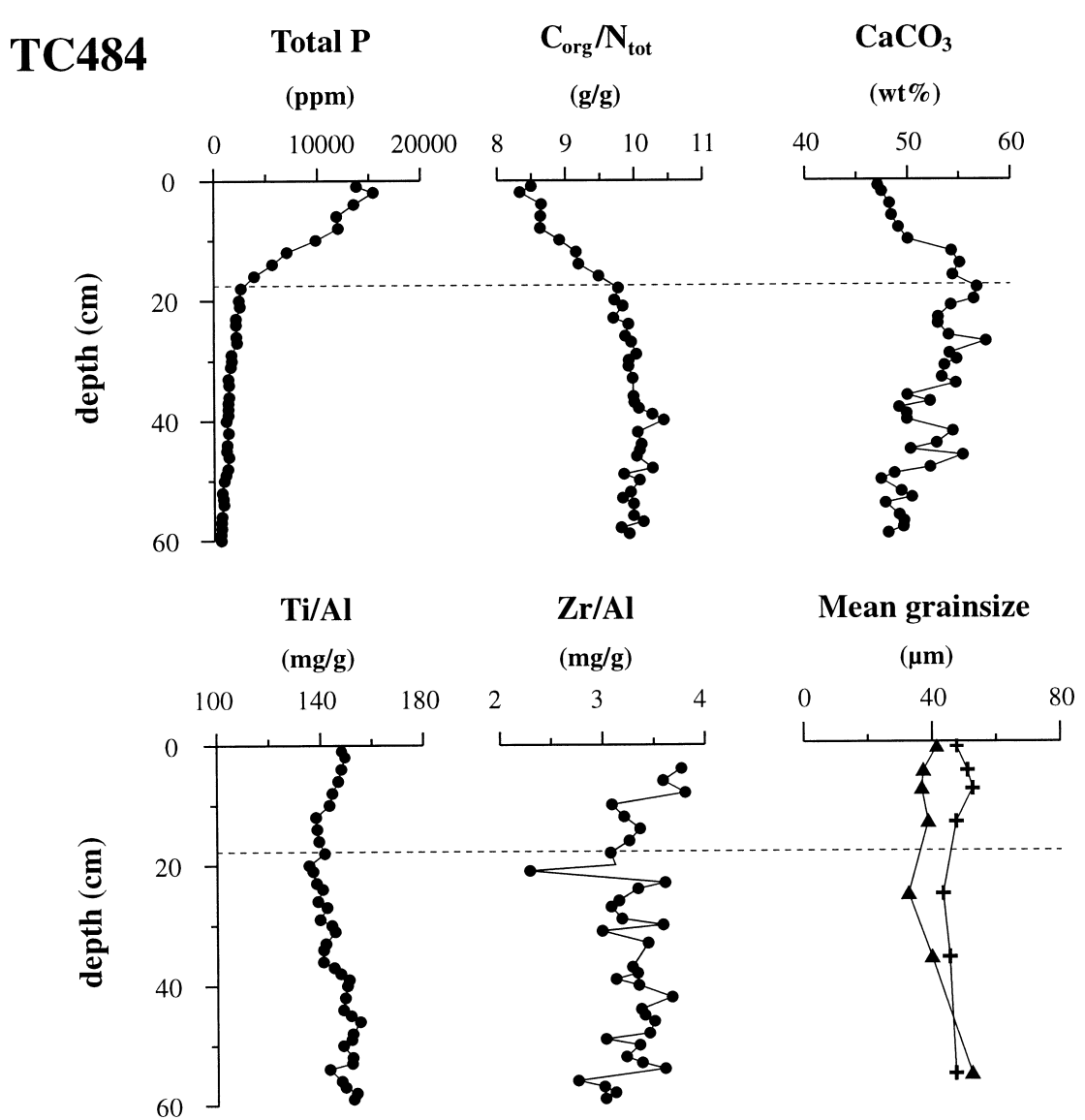

Fig. 4. Profiles of tripcore 484 (TC484) for total $\mathrm{P}(\mathrm{ppm}), \mathrm{C}_{\text {org }} / \mathrm{N}_{\text {tot }}$ ratio (g/g), $\mathrm{CaCO}_{3}(\mathrm{wt} \%)$, Ti/Al (mg/g), $\mathrm{Zr} / \mathrm{Al}$ (mg/g) and mean grainsize $(\mu \mathrm{m})($ bulk $(\mathbf{\Lambda})$ and decarbonated $(+)$ sediment). The dotted line indicates the depth above which the P concentration increases sharply. The top $10 \mathrm{~cm}$ of TC484 were lost during core recovery.

not shown) and $\mathrm{P}_{\text {res }}$ contents, indicates that the $\mathrm{P}_{\mathrm{res}}$ fraction is equal to organic $\mathrm{P}$.

The sediments of $\mathrm{BC} 451$ and $\mathrm{BC} 455$ have higher organic carbon $\left(\mathrm{C}_{\text {org }}\right)$ contents than those of $\mathrm{BC} 484$ (Table 1). The $\mathrm{C}_{\text {org }} / \mathrm{N}_{\text {tot }}$ weight ratio in TC484 increases with depth till $18 \mathrm{~cm}$, where it reaches a constant value of 10 (Fig. 4). A sharp upward increase of the $\mathrm{P}$ content occurs above this depth. The Cacarbonate content is lower in the upper $12 \mathrm{~cm}$ of TC484, relative to the deeper part. Ti and $\mathrm{Zr}$ contents, which have been divided by $\mathrm{Al}$ to reveal changes not related to variations in terrestrial input, are fairly constant with depth. The mean grainsize of both bulk and decarbonated sediment samples is relatively constant with depth. The fish debris concentration (numbers per gram of the 150-595 $\mu \mathrm{M}$ sieve fraction) decreases with depth in BC484 (Fig. 5), and correlates reasonably well with the total $\mathrm{P}$ concentration. The amount of detectable fish debris, however, constitutes only a minor fraction of the total $\mathrm{P}$ since other phosphatised particles are more abundant. The fish debris concentration in BC451 and BC455 show a larger variability with depth. The lower concentrations of fish particles in these sediments compared to BC484 can probably be attributed to dilution by detrital material supplied by the Indus river.

\subsection{Microscopic observations and calibrated ${ }^{14} \mathrm{C}$ ages of apatite macro particles in BC484}

Microscopic observations and microprobe analysis allowed the identification of three types of apatite 


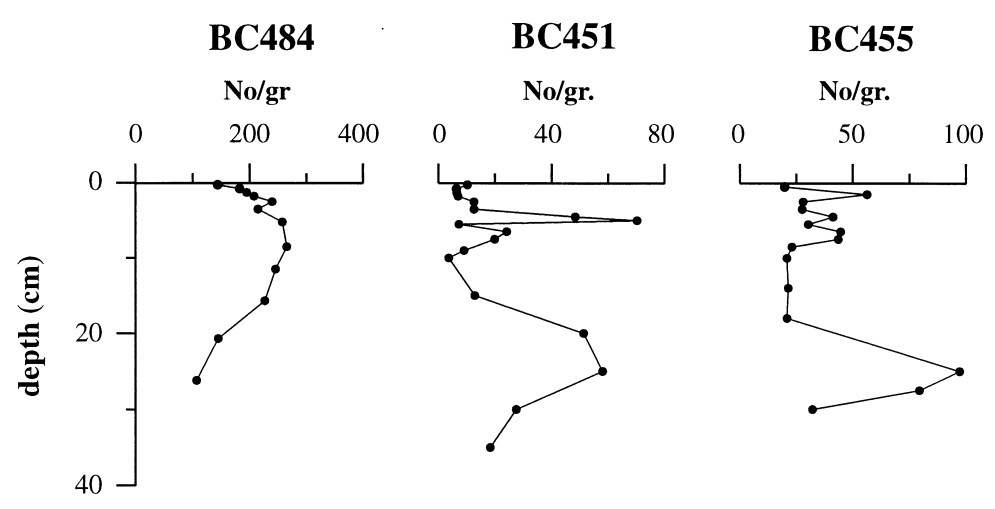

Fig. 5. Concentration of fish debris in BC484, BC451 and BC455 (numbers per gram sediment).

macro particles in BC484: coated foraminifers, phosphatised pellets and fish debris.

Coated foraminifers. These foraminifers constitute the bulk of the large phosphate grains. Most of the foraminifers in the top $10 \mathrm{~cm}$ of $\mathrm{BC} 484$ have a brown to black appearance caused by coatings and fillings. The foraminifer tests without coating look well preserved and do not show signs of calcite replacement or dissolution. Other particles consist of moulds, resembling the ovoid shape of the foraminifers. In the deeper part of the boxcore, coated foraminifers become less frequent. The $\mathrm{F} / \mathrm{P}_{2} \mathrm{O}_{5}$ ratio of the coating/fillings is lower $(0.056)$ than the ratio for substituted francolite $(0.148$; McClellan, 1980), which have previously been observed in relatively young phosphorites (Price and Calvert, 1978; Thomson et al., 1984; Baker and Burnett, 1988). Calibrated ${ }^{14} \mathrm{C}$ ages for coated foraminifers are higher than "clean" (uncoated) foraminifers in the same sediment interval (Table 3).

Table 3

Calibrated ${ }^{14} \mathrm{C}$ ages for non-coated foraminifers, coated foraminifers and phosphatised pellets in $\mathrm{BC} 484$ and pistoncore 484 . The ${ }^{14} \mathrm{C}$ age for coated foraminifers is the age of the total particles, i.e. including carbonate and apatite $\mathrm{C}$

\begin{tabular}{lllr}
\hline $\begin{array}{l}\text { Core depth } \\
(\mathrm{cm})\end{array}$ & $\begin{array}{l}\text { Pellets } \\
(\mathrm{yr})\end{array}$ & $\begin{array}{l}\text { Coated } \\
\text { foraminifers } \\
(\mathrm{yr})\end{array}$ & $\begin{array}{l}\text { Clean } \\
\text { foraminifers } \\
(\mathrm{yr})\end{array}$ \\
\hline $2 \mathrm{~cm}$ & $6890 \pm 80$ & $\begin{array}{l}6385 \pm 70, \\
6200 \pm 60\end{array}$ & $373 \pm 40$ \\
& & $8800 \pm 60$ & $4670 \pm 60$ \\
$24.5 \mathrm{~cm}$ & - & - & $12,840 \pm 60$ \\
$\begin{array}{l}\text { Top piston } \\
\text { core }\end{array}$ & - & & \\
\hline
\end{tabular}

Phosphatised pellets. These pellets have ovoid to cylindrical shapes and a maximum length of $\sim 3 \mathrm{~mm}$. Their surface is blackish/brownish and usually smooth. Thin slides of samples reveal no internal structures indicating that the pellets are probably composed of apatite micro crystals. The average $\mathrm{F} / \mathrm{P}_{2} \mathrm{O}_{5}$ ratio is 0.11 . The number of phosphatised pellets decreases with depth, but they are still present in the deepest part of the boxcore. Phosphatised pellets at $2 \mathrm{~cm}$ depth have a calibrated ${ }^{14} \mathrm{C}$ age of $6890 \mathrm{yr}$, and are thus slightly older than the coated foraminifers from the same depth (Table 3 ).

Fish debris. This debris is present in a range of forms and sizes $(<2 \mathrm{~mm})$. The large parts are easily recognisable as vertebra (scales and bones) and have a spongeous structure. Some particles are covered by small brown crystals consisting of francolite.

\subsection{Application of the model}

The fixed parameters $\left(L_{1}, L_{2}, \varphi, D_{\mathrm{s}}, D_{\mathrm{b}}, \omega, C_{0}, C_{\mathrm{s}}\right.$, $C_{\mathrm{a}}, k_{\mathrm{s}}, J_{\mathrm{Mx}=0}, M_{\infty}$ and $G_{\infty}$ ) used for the model and their sources are listed in Table 4. Considering the low BWO concentrations and the high sedimentary organic matter contents, oxygen will be consumed in the upper few millimetres in these sediments. Therefore, $L_{1}$ for BC451 was set at $1 \mathrm{~mm}$. For BC455, $L_{1}$ is probably somewhat larger $(\sim 2 \mathrm{~mm})$, as it is located near the base of the OMZ. The porewater equilibrium concentration for francolite formation $\left(C_{\mathrm{a}}\right)$ may vary between 0.4 and $11 \mu \mathrm{M}$ for $\mathrm{pH} 4$ (Atlas and Pytkowicz, 1977). For impure francolites or a precursor phase this value may be higher. Here, a 
Table 4

Values for the fixed and fitted parameters for BC451 and BC455 as used in the diagenetic P model

\begin{tabular}{lllll}
\hline Fixed parameters & Units & BC451 & BC455 & Source \\
\hline$L_{1}$ & $\mathrm{~cm}$ & 0.1 & 0.2 & See text \\
$L_{2}$ & $\mathrm{~cm}$ & 2.8 & 3.8 & Van der Weijden et al., 1999 \\
$\phi$ & $\mathrm{cm}^{3} \mathrm{~cm}^{-3}$ & 0.82 & 0.84 & Average porosity \\
$D_{\mathrm{s}}$ & $\mathrm{cm}^{2} \mathrm{~d}^{-1}$ & $3.0 \times 10^{-1}$ & $2.8 \times 10^{-1}$ & See appendix \\
$D_{\mathrm{b}}$ & $\mathrm{cm}^{2} \mathrm{~d}^{-1}$ & $5.0 \times 10^{-3}$ & $3.6 \times 10^{-3}$ & Boudreau, 1994 \\
$\omega$ & $\mathrm{cm} \mathrm{kyr}^{-1}$ & 28 & 16 & Table 1 \\
$C_{0}$ & $\mu \mathrm{M}$ & 3.7 & 3.4 & Bottom water concentration \\
$C_{\mathrm{s}}$ & $\mu \mathrm{M}$ & 3.7 & 3.4 & Bottom water concentration \\
$C_{\mathrm{a}}$ & $\mu \mathrm{M}$ & 10 & 10 & See text \\
$k_{\mathrm{s}}$ & $\mathrm{d}^{-1}$ & $5.0 \times 10^{-1}$ & $5.0 \times 10^{-1}$ & Slomp et al., 1998 \\
$J_{\mathrm{Mx}=0}$ & $\mu \mathrm{mol} \mathrm{cm}{ }^{-2} \mathrm{yr}^{-1}$ & $7.0 \times 10^{-2}$ & $4.0 \times 10^{-2}$ & See text \\
$M_{\infty}$ & $\mu \mathrm{mol} \mathrm{g}$ & 1 & Conc. in bottom sample \\
$G_{\infty}$ & $\mu \mathrm{mol} \mathrm{g}$ & 5.8 & Conc. in bottom sample \\
Fitted parameters & & 4.1 & & \\
$k_{\mathrm{g}}$ & $\mathrm{d}^{-1}$ & & $8.2 \times 10^{-3}$ & \\
$k_{\mathrm{a}}$ & $\mathrm{d}^{-1}$ & $3.1 \times 10^{-3}$ & $1.4 \times 10^{-3}$ & \\
$k_{\mathrm{m}}$ & $\mathrm{d}^{-1}$ & $7.7 \times 10^{-4}$ & $1.2 \times 10^{-5}$ & \\
$J_{\mathrm{Gx}=0}$ & $\mu \mathrm{mol} \mathrm{cm}{ }^{-2} \mathrm{yr}^{-1}$ & 6.1 & 3.2 & \\
$J_{\mathrm{Ax}=0}$ & $\mu \mathrm{mol} \mathrm{cm} \mathrm{yr}^{-1}$ & $2.5 \times 10^{-1}$ & $9.3 \times 10^{-2}$ & \\
\hline
\end{tabular}

$C_{\mathrm{a}}$ concentration of $10 \mu \mathrm{M}$ was used for both cores, which equals the (constant) porewater phosphate concentration at greater sediment depth (Schenau, 1999). The deposition rate of Fe-bound $\mathrm{P}\left(J_{\mathrm{Mx}=0}\right)$ was estimated from the mass accumulation rate, an average reactive iron concentration of $6000 \mathrm{ppm}$ (equal to the concentration in surface sediments below the OMZ) and an atomic Fe/P ratio of 20 for the newly deposited reducible iron particles (Schenau, 1999).

The model fits agree reasonably well with the measured data (Fig. 6), with the exception of the porewater profiles of BC451 and BC455. A good model fit to the porewater phosphate concentration of $\mathrm{BC} 455$ is only obtained when limited francolite formation takes place (i.e. setting $k_{\mathrm{a}}$ to $10^{-6} \mathrm{~d}^{-1}$ and keeping all other parameters the same; Fig. 6). Fitted values for $k_{\mathrm{g}}, k_{\mathrm{a}}$, $k_{\mathrm{m}}, J_{\mathrm{Ax}=0}$ and $J_{\mathrm{Gx}=0}$ are listed in Table 4. The calculated phosphate production and removal rates are given in Table 5.

\section{Discussion}

\subsection{Authigenic apatite formation}

Three indicators have been studied to examine whether phosphogenesis is currently taking place in the sediments located within the OMZ of the Arabian Sea (Ruttenberg and Berner, 1993): (1) porewater phosphate and fluoride concentrations; (2) the saturation state of francolite; and (3) solid-phase authigenic $\mathrm{P}$ concentrations.

Porewater phosphate and fluoride concentrations. A decrease in porewater phosphate and fluoride concentration with depth is indicative for $\mathrm{P}$ and $\mathrm{F}$ removal to the solid phase (Jahnke et al., 1983; Ruttenberg and Berner, 1993). The main sink for phosphate and fluoride in anoxic sediments is authigenic apatite (Froelich et al., 1983; Jahnke et al., 1983; Froelich et al., 1988; Ruttenberg and Berner, 1993). Consequently, the decrease in dissolved $P$ and F with depth in BC484 and BC451 is interpreted as the result of francolite precipitation. The increase of ammonium and alkalinity with depth in all three boxcores implies that dissolved phosphate is also produced as the result of ongoing organic matter degradation. The rather constant phosphate concentration in $\mathrm{BC} 455$, therefore, indicates that in this boxcore also phosphate is removed and incorporated into a solid phase. In BC484 the negative porewater gradient of both phosphate and fluoride is non-linear, which implies that precipitation takes place in a zone 

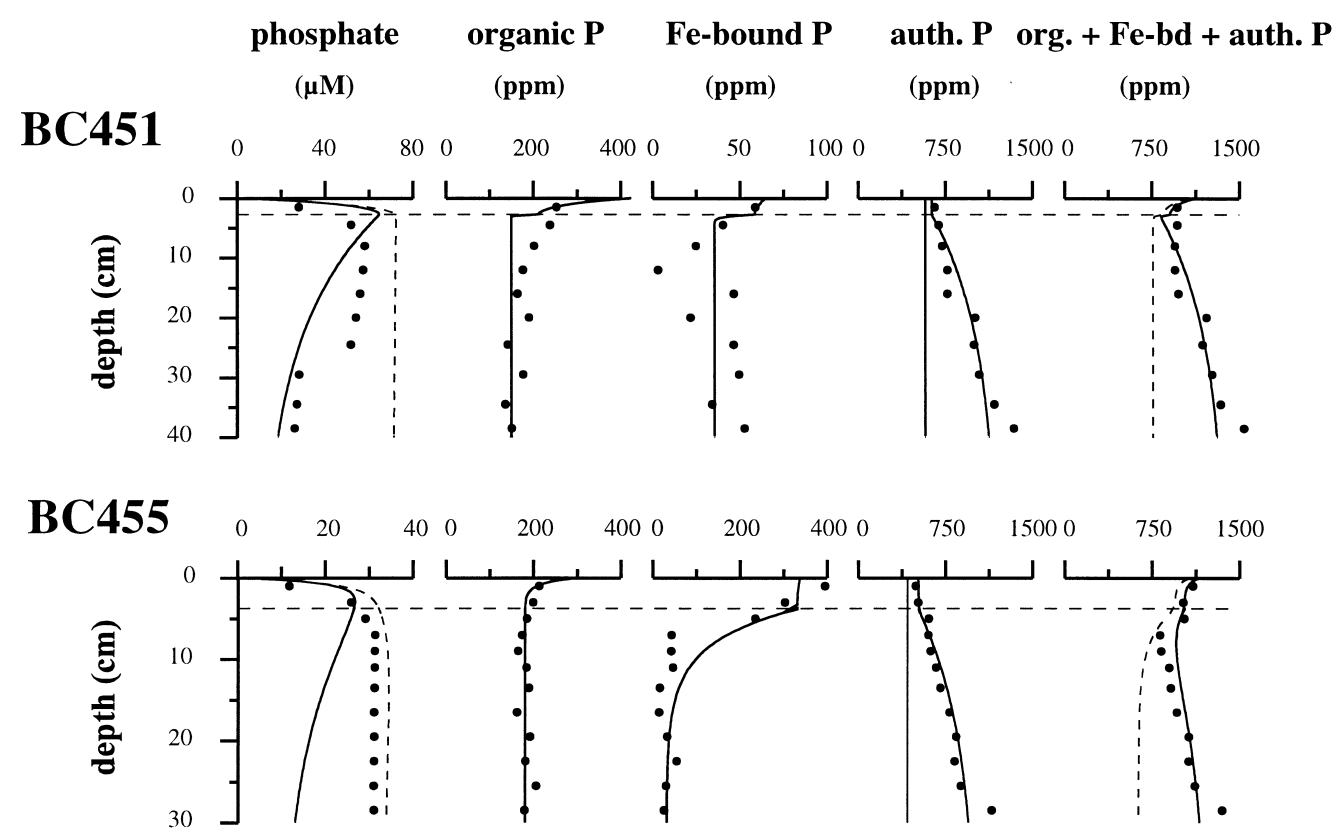

Fig. 6. Model fits (solid lines) to the profiles of porewater phosphate, organic $\mathrm{P}$ (equal to $\mathrm{P}_{\mathrm{res}}$ ), Fe-bound $\mathrm{P}$ ( $\mathrm{P}_{\mathrm{Fe}}$ ), authigenic $\mathrm{P}$ (equal to $\mathrm{P}_{\mathrm{NH} 4 \mathrm{Cl}}+\mathrm{P}_{\mathrm{CFA}}$ ), and the sum of these three solid phase $\mathrm{P}$ fractions. The horizontal dotted line indicates the depth of bioturbation. The vertical solid line in the authigenic $\mathrm{P}$ profiles represents the $\mathrm{P}_{\mathrm{NH} 4 \mathrm{Cl}}+\mathrm{P}_{\mathrm{CFA}}$ concentration which is not related with in situ authigenic $\mathrm{P}$ formation (i.e. $\mathrm{P}$ associated with fish debris or carbonates, easily exchangeable $\mathrm{P}$, or redeposited francolite). The vertical dotted lines represent the scenario where limited francolite formation takes place (i.e. $k_{\mathrm{a}}=10^{-6}$, leaving all other parameters the same).

comprising the upper $10 \mathrm{~cm}$ of the sediment. The nearly linear gradient of fluoride in BC451 and $\mathrm{BC} 455$ suggests that incorporation of $\mathrm{F}$ occurs at some greater depth.

Precipitation rates of francolite (or a precursor

Table 5

Phosphate production and removal rates for $\mathrm{BC} 451$ and $\mathrm{BC} 455$ as calculated with the diagenetic $\mathrm{P}$ model

\begin{tabular}{lll}
\hline & $\begin{array}{l}\mathrm{BC} 451 \\
\left(\mu \mathrm{mol} \mathrm{cm} \mathrm{cr}^{-2}\right)\end{array}$ & $\begin{array}{l}\mathrm{BC} 455 \\
\left(\mu \mathrm{mol} \mathrm{cm} \mathrm{cm}^{-2} \mathrm{yr}^{-1}\right)\end{array}$ \\
\hline $\begin{array}{l}\text { Phosphate production } \\
\text { Organic P release }\end{array}$ & 6.05 & 3.17 \\
$\begin{array}{l}\text { Fe-bound P desorption } \\
\text { Total }\end{array}$ & 0.1 & 0.13 \\
Phosphate removal & 6.15 & 3.30 \\
Benthic P flux & & \\
$\begin{array}{l}\text { Diffusive P flux at bottom } \\
\text { Authigenic P formation }\end{array}$ & 0.04 & 3.07 \\
P adsorption to iron oxides & 0.04 & 0.01 \\
Total & 6.15 & 0.13 \\
\hline
\end{tabular}

phase) were estimated from the downward diffusing phosphate and fluoride fluxes (see Appendix A; Table 6). The fluoride flux $\left(J_{\mathrm{F}}\right)$ was converted into a P precipitation rate $\left(J_{\mathrm{P}(\mathrm{F})}\right)$, in order to allow a direct comparison with the phosphate flux $\left(J_{\mathrm{P}}\right)$. In BC484, $J_{\mathrm{P}}$ and $J_{\mathrm{P}(\mathrm{F})}$ are similar at $4 \mathrm{~cm}$ depth, indicating that the removal of phosphate and fluoride with depth is indeed due to francolite formation. The downward fluoride flux in the top centimetre is higher than at $4 \mathrm{~cm}$ depth (Table 6), which implies that francolite precipitation is also occurring in the top $4 \mathrm{~cm}$ of the sediment. In BC451 and BC455, $J_{\mathrm{P}}$ is lower than $J_{\mathrm{P}(\mathrm{F})}$ (Table 6). A similar difference between interstitial phosphate and fluoride removal fluxes was observed by Schuffert et al. (1994) for sediments off western Mexico. The $\mathrm{F}$ flux into the sediment probably provides the best direct measure for francolite precipitation rates, because seawater is the dominant source for $\mathrm{F}$ in marine sediments (Froelich et al., 1983).

The francolite saturation state. This has been calculated using porewater data, the average stoichiometry 
Table 6

Calculations for the downward flux of phosphate and fluoride (see Appendix A) ( $\phi$ - average porosity, $z$ - depth of the of concentration gradient, $\mathrm{d} P / \mathrm{d} z$ - average linear negative porewater phosphate gradient, $\mathrm{d} F / \mathrm{d} z$ - average linear negative porewater fluoride gradient (for $\mathrm{BC} 484$ the phosphate/fluoride gradient was taken at a specific depth), $J_{\mathrm{P}}$ - downward flux of phosphate (P removal rate by authigenic apatite formation), $J_{\mathrm{F}}$ - downward flux of fluoride ( $\mathrm{F}$ removal rate by authigenic apatite formation), $J_{\mathrm{P}(\mathrm{F})}-\mathrm{P}$ removal rate by authigenic apatite formation, based on the downward flux of fluoride, $J_{\mathrm{p}}$ model - the calculated authigenic $\mathrm{P}$ formation rate according to the diagenetic $\mathrm{P}$ model)

\begin{tabular}{lllllllll}
\hline Boxcore & $\phi$ & $\begin{array}{l}z \\
(\mathrm{~cm})\end{array}$ & $\begin{array}{l}-d \mathrm{P} / d \mathrm{z} \\
\left.(\mu \mathrm{M} \mathrm{cm})^{-1}\right)\end{array}$ & $\begin{array}{l}-d \mathrm{~F} / d \mathrm{z} \\
\left(\mu \mathrm{M} \mathrm{cm} \mathrm{cm}^{-1}\right)\end{array}$ & $\begin{array}{l}J_{\mathrm{P}} \\
\left(\mu \mathrm{mol} \mathrm{cm} \mathrm{cm}^{-2} \mathrm{yr}^{-1}\right)\end{array}$ & $\begin{array}{l}J_{\mathrm{F}} \\
\left(\mu \mathrm{mol} \mathrm{cm}^{-2} \mathrm{yr}^{-1}\right)\end{array}$ & $\begin{array}{l}J_{\mathrm{P}(\mathrm{F})} \\
\left(\mu \mathrm{mol} \mathrm{cm}^{-2} \mathrm{yr}^{-1}\right)\end{array}$ & $\begin{array}{l}J_{\mathrm{p}} \mathrm{model} \\
\left(\mu \mathrm{mol} \mathrm{cm}^{-2} \mathrm{yr}^{-1}\right)\end{array}$ \\
\hline 484 & 0.78 & 4.1 & 12.51 & 2.85 & 1.04 & 0.45 & 1.08 \\
484 & & 1 & & 7.1 & & 1.08 & 2.6 & 0.24 \\
451 & 0.82 & & 1.34 & 0.73 & 0.12 & 0.126 & 0.3 & 0.13 \\
455 & 0.84 & & 0.01 & 0.44 & 0.001 & 0.069 & 0.16 & 0.16 \\
\hline
\end{tabular}

of francolite $\left(\mathrm{Ca}_{9.54} \mathrm{Na}_{0.33} \mathrm{Mg}_{0.13}\left(\mathrm{PO}_{4}\right)_{4.8}\left(\mathrm{CO}_{3}\right)_{1.2} \mathrm{~F}_{2.48}\right.$; Chien, 1972), and the solubility product of carbonate fluorapatite $\left(K_{\mathrm{sp}}\right)$ (Jahnke et al., 1983; Ruttenberg and Berner, 1993). The solubility product of recently formed marine apatite has been shown to depend on the aqueous activity of $\mathrm{CO}_{3}^{2-}$ (Jahnke et al., 1983). Therefore, the solubility product has been calculated for each depth, using $\mathrm{CO}_{3}^{2-}$ concentrations estimated from $\mathrm{pH}$ and alkalinity data. In the top of the sediment of all cores the ion activity product (IAP) exceeds the solubility product, indicating supersaturation of the porewater with respect to the francolite (Fig. 2). With depth, porewaters become undersaturated again. This suggests that precipitation of francolite or another Ca-phosphate mineral is most likely occurring in the upper $20 \mathrm{~cm}$ of the sediment.

Solid-phase authigenic phosphorus. The most direct indication for ongoing phosphogenesis is an increase of the solid-phase authigenic apatite fraction with sediment depth (Ruttenberg and Berner, 1993; Slomp et al., 1996; Louchouarn et al., 1997). Although the $\mathrm{P}_{\mathrm{CFA}}$ fraction remains constant in BC451 and BC455 (Fig. 3, step 4), the $\mathrm{P}_{\mathrm{NH} 4 \mathrm{Cl}}$ concentrations increase with depth. To determine what $\mathrm{P}$ fraction is responsible for this increase, the $2 \mathrm{M}$ $\mathrm{NH}_{4} \mathrm{Cl}$ extraction was performed sequentially eight times for some sediment samples from the base of $\mathrm{BC} 455$ and $\mathrm{BC} 451$. The release patterns for $\mathrm{P}$ and $\mathrm{Ca}$ show that the $\mathrm{P}$ concentration in the solvent starts to increase once the $\mathrm{Ca}$ concentration has dropped, indicating that the phosphorus fraction associated with $\mathrm{P}_{\mathrm{NH} 4 \mathrm{Cl}}$ starts to dissolve once all Ca-carbonates have been extracted (Fig. 7). Consequently, the $\mathrm{P}_{\mathrm{NH} 4 \mathrm{Cl}}$ fraction must be associated with a Ca-phosphate mineral. Fish debris, which consists primarily of hydroxyapatite, is, in contrast to authigenic or detrital apatite, highly soluble in $2 \mathrm{M} \mathrm{NH}_{4} \mathrm{Cl}$ (Schenau and De Lange, 2000). The number of fish debris, as counted in the 150-595 $\mu \mathrm{m}$ sieve fraction, however, does not clearly increase with depth (Fig. 5). Consequently, it is unlikely that changes in the biogenic apatite contents can account for the observed $\mathrm{P}_{\mathrm{NH} 4 \mathrm{Cl}}$ profiles. In addition, an increase in sediment accumulation rates cannot be responsible for a possible dilution of the $\mathrm{P}$ fractions, as high resolution records from Arabian Sea sediment cores show that sedimentation rates during the Late Holocene remained constant (Sirocko et al., 1993). Therefore, we argue that the increase of the $\mathrm{P}_{\mathrm{NH} 4 \mathrm{Cl}}$ fraction with depth in $\mathrm{BC} 451$ and $\mathrm{BC} 455$ is the result of precipitation of an authigenic Ca-phosphate mineral, which is more soluble than francolite.

Laboratory experiments have shown that francolite precipitation at high phosphate concentrations is a two-step process. First, an amorphous, F-poor precursor is formed, which subsequently acts as a substrate for francolite precipitation (Van Cappellen and Berner, 1991; Krajewski et al., 1994). This process is much faster than the direct nucleation of francolite from solution, which occurs at lower phosphate concentrations. The easily dissolvable Ca-phosphate in BC451 and BC455 may be identified as a precursor to francolite formation. This would also explain why fluoride incorporation occurs at a greater depth than the formation of the $\mathrm{P}_{\mathrm{NH} 4 \mathrm{Cl}}$ phase. Probably, an F-poor Ca-phosphate mineral precipitates in the top $10 \mathrm{~cm}$ of the sediment at the highest interstitial phosphate concentrations, and is converted into francolite deeper in the sediment. Uncoupling of interstitial phosphate and fluoride removal has previously been observed in 


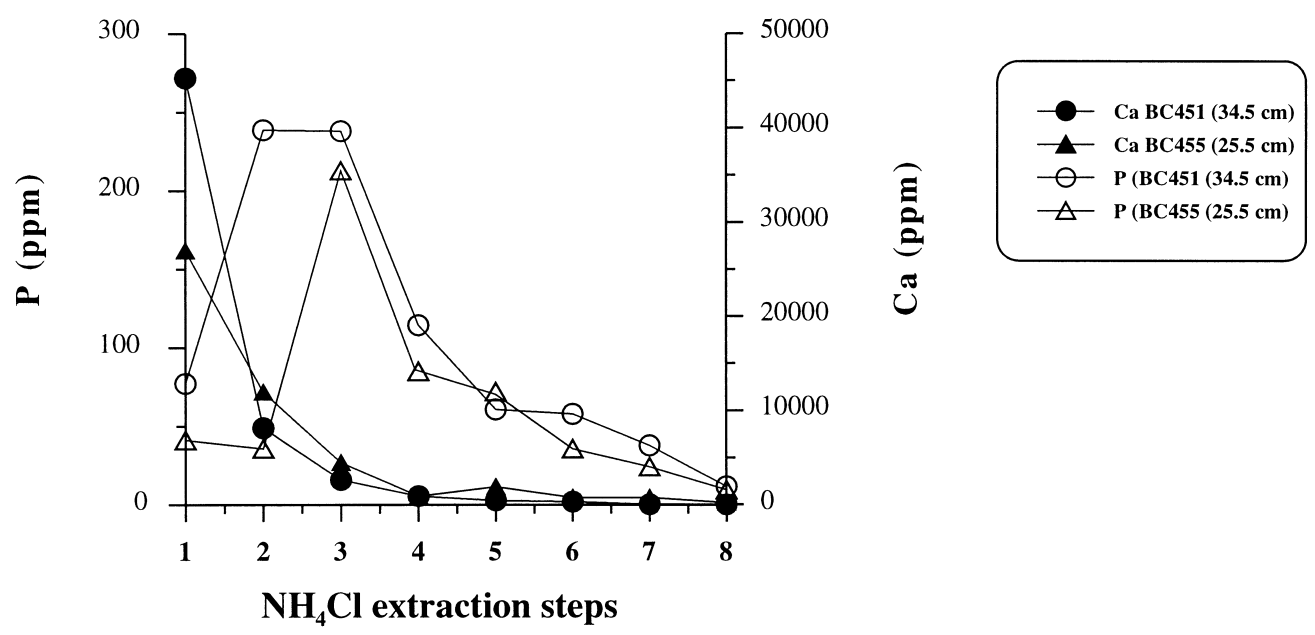

Fig. 7. The $\mathrm{P}$ and $\mathrm{Ca}$ concentrations (ppm) in the solutions of the $8 \times \mathrm{NH}_{4} \mathrm{Cl}$ sequential extraction for two sediment samples (BC451, $34.5 \mathrm{~cm}$ depth; BC455, $25.5 \mathrm{~cm}$ depth).

Peru Margin sediments (Froelich et al., 1988). Possibly, high concentrations of fish debris in the sediments of the Pakistan Margin are acting as a template for precipitation of a Ca-phosphate mineral (Föllmi, 1996), enabling rapid authigenic apatite precipitation under relatively low phosphate concentrations. Porewater profiles indicate that the transformation of the precursor into francolite takes at least a few thousand years.

Summarising, sequential extraction results and porewater flux calculations indicate that a Ca-phosphate mineral is precipitating in sediments located within the Arabian Sea OMZ during early diagenesis. In $\mathrm{BC} 484$, francolite precipitates in the upper $10 \mathrm{~cm}$ of the sediment. In BC451 and BC455, however, a precursor phase is formed, which is subsequently converted into francolite deeper in the sediment.

\subsection{Implications of the model}

The model results confirm that the increase of the solid-phase P with depth at stations BC451 and BC455 can be explained by early diagenetic phosphogenesis. The calculated francolite formation rates correspond reasonably well with the downward $J_{\mathrm{P}(\mathrm{F})}$ fluxes (Table 6). The values of the rate constants $k_{\mathrm{m}}$ and $k_{\mathrm{a}}$ are in line with ranges estimated in other studies (Slomp et al., 1996, 1998). Fitted values for $k_{\mathrm{g}}$ correspond to rate constants for highly reactive organic matter (Boudreau, 1997). Model results suggest that phosphogenesis is fuelled by phosphate release from organic matter in the surface sediments. In order to reproduce the high subsurface porewater phosphate concentrations organic $\mathrm{P}$ inputs of, respectively, 6.1 and $3.2 \mu \mathrm{mol} \mathrm{P} \mathrm{cm}{ }^{-2} \mathrm{yr}^{-1}$ for BC451 and $\mathrm{BC} 455$ are required (Table 5). The potential organic carbon flux arriving at the sediment water interface $\left(J_{\mathrm{Cx}=0} \mathrm{gC} \mathrm{m}^{-2} \mathrm{yr}^{-1}\right)$ can be estimated with the transfer equation (Berger and Herguera, 1992):

$J_{\mathrm{Cx}=0}=2 \mathrm{PP}^{0.5} \times(\mathrm{PP} / 100) \times(1 / z+0.025)$

where $\mathrm{PP}$ is the primary productivity rate $\left(\mathrm{gC} \mathrm{m}^{-2} \mathrm{yr}^{-1}\right)$, and $z$ the water depth in units of $100 \mathrm{~m}$. Assuming an average primary productivity rate of $300 \mathrm{gC} \mathrm{m}^{-2} \mathrm{yr}^{-1}$ for the northern Arabian Sea (Qasim, 1982), the potential $J_{\mathrm{Cx}=0}$ flux amounts to 23 and $13 \mathrm{gC} \mathrm{m}^{-2} \mathrm{yr}^{-1}$ for $\mathrm{BC} 451$ and $\mathrm{BC} 455$, respectively. This corresponds to a potential $J_{\mathrm{Gx}=0}$ flux of 1.7 and $0.9 \mu \mathrm{molP} \mathrm{cm} \mathrm{yr}^{-2} \mathrm{yr}^{-1}$, respectively. Apparently, the values for the $J_{\mathrm{Gx}=0}$ flux needed to reproduce the high subsurface phosphate concentrations are unrealistically high. There are three possible explanations for this. Firstly, the model describes organic matter decomposition with one first-order rate constant. As a result, the model predicts that all degradable organic $\mathrm{P}$ is mineralised in the upper few centimetres of the sediment (Fig. 6). This is an overly 
simplistic description because organic matter degradation continues deeper in the sediment, as is demonstrated by the increasing alkalinity and ammonium concentrations with depth (Fig. 2). When in the model calculations relatively more organic matter degradation and phosphate production would occur deeper in the sediment, a lower $J_{\mathrm{Gx}=0}$ input flux would be sufficient. Secondly, the measured phosphate profiles may not represent a steady-state situation. In the Arabian Sea productivity is highly seasonal, and therefore deposition rates of reactive $\mathrm{P}$, subsequent phosphate regeneration and authigenic $\mathrm{P}$ formation may vary through the year. This may also explain the discrepancy between the observed and the modelled phosphate porewater profiles. Thirdly, dissolution of fish debris in the upper few centimetres of the sediment may provide an additional source of phosphate.

Early diagenetic iron redox cycling has been shown to be important for phosphogenetic processes in certain marine environments (e.g. Heggie et al., 1990; Sundby et al., 1992; Slomp et al., 1996). Phosphate liberated from organic matter degradation or fish debris dissolution is scavenged by Fe-hydroxides in the oxic part of the sediments. Upon burial, these iron oxides are transferred to the suboxic part of the sediment and will be reduced, resulting in desorption of phosphate. The porewater phosphate concentration will increase, until francolite or a precursor phase starts to precipitate. Model results indicate that phosphate sorption does not affect the benthic P flux leaving the sediments (Table 5). In addition, the phosphate desorption from iron oxides provides only a minor source relative to organic matter degradation in BC451. The oxidised surface layer is too thin to induce effective iron cycling as a result of the low BWO concentrations and the high reactive organic matter contents. Early diagenetic iron cycling is relatively more important in BC455. However, reducing $L_{1}$ in the model to zero (i.e. no sorption of phosphate to iron oxides) and leaving all other parameters the same, results in a reduction of the francolite formation rate of only $20 \%$. The relative importance of iron cycling would increase when a higher reaction rate constant for phosphate adsorption $\left(k_{\mathrm{s}}\right)$ is used, as has been measured in some oxygenated environments. However, it can be expected that for these dysoxic conditions the adsorption rate for phosphate is in the lower part of the range of values estimated for oxygenated environments (Slomp et al., 1998). Apparently, "iron pumping" is not driving phosphogenesis in the sediments located within the OMZ.

Holocene sediments of the Pakistan continental margin between 300 and $900 \mathrm{~m}$ water depth are frequently finely laminated, indicating lack of bioturbation (Schulz et al., 1996; Von Rad et al., 1999). In the sediments of BC451 and BC455, however, some benthic activity occurs as is demonstrated by the presence of benthic foraminifera (Jannink et al., 1998) and the absence of laminae. A recent study reported a mean mixed-layer depth of $4.6 \pm 0.2 \mathrm{~cm}$ and a mean $D_{\mathrm{b}}$ of $0.003 \pm 0.0017 \mathrm{~cm}^{2} \mathrm{~d}^{-1}$ for Arabian Sea slope sediments located within the OMZ (Smith et al., 2000), which are similar to the values used in the model (Table 4). Extensive bioturbation enhances phosphate release to the water column, reduces the accumulation of dissolved phosphate and, accordingly, inhibits phosphogenesis (Filippelli and Delaney, 1994). Model results, however, suggest that the occurrence of some bioturbation is essential to initiate francolite precipitation in these sediments. For example, limiting the zone of bioturbation $\left(L_{2}\right)$ in BC451 from $2.8 \mathrm{~cm}$ to $2 \mathrm{~mm}$ would require a totally unrealistic 10-fold increase of the organic $\mathrm{P}$ input flux

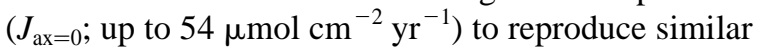
porewater and solid-phase $\mathrm{P}$ profiles. The same is true for a substantial decrease of the bioturbation rate constant $\left(D_{\mathrm{b}}\right)$. Downward mixing of reactive $\mathrm{P}$ is necessary to build up the subsurface phosphate concentrations. Without bioturbation, reactive $\mathrm{P}$ is primarily regenerated at the sediment surface and subsequently lost to the overlying bottom water. These results indicate that early diagenetic phosphogenesis rates may be seriously diminished under true anoxic bottom water conditions. This mechanism may reduce the phosphorus burial efficiency under oxygendepleted bottom water conditions, as has been observed by Ingall and Jahnke (1994).

\subsection{Phosphorite formation in BC484}

High francolite contents just below the sediment water interface as observed in $\mathrm{BC} 484$ have previously been documented for the continental margins of Peru (Burnett et al., 1982; Froelich et al., 1988), western Mexico, Baja California (Jahnke et al., 1983; Schuffert 
et al., 1994, 1998), Namibia (Thomson et al., 1984), Eastern Australia (Heggie et al., 1990) and western India (Rao and Lamboy, 1996). Many of these phosphorite deposits have been identified as lag deposits (Kolodny, 1981; Garrison and Kastner, 1990). Beside redeposition processes, winnowing has been suggested to play an important role in the formation of phosphorites (e.g. Glenn and Arthur, 1988; Glenn et al., 1994). Since phosphorite particles have a higher specific gravity than the surrounding detrital particles, bottom currents could wash away the finer, lighter particles and thus concentrate $\mathrm{P}$ in the top of the sediment. Winnowing causes low sedimentation rates, which in turn may enhance the growth of phosphorite nodules by keeping them in the zone of active diagenesis. (Burnett et al., 1983). On the other hand, the effects of winnowing may obstruct phosphogenesis, not only by reducing the flux of reactive $\mathrm{P}$ into the sediment by enhancing the degradation and removal of organic matter and fish debris at the sediment surface, but also by increasing the permeability and, therefore, inhibiting the build up of phosphate in the porewater (Van Cappellen and Berner, 1988; Filippelli and Delaney, 1994). To establish the origin of the phosphorite deposit in $\mathrm{BC} 484$, the processes of winnowing and redeposition have been examined.

\subsubsection{Winnowing}

The high phosphorus concentration in the top $20 \mathrm{~cm}$ of BC484 could be the result of winnowing, which is an important process affecting the continental slope sediments on the Oman Margin (Shimmield et al., 1990; Pedersen et al., 1992). Evidence for winnowing can be obtained from sedimentary $\mathrm{C} / \mathrm{N}$ ratios, total carbonate concentrations, $\mathrm{Ti} / \mathrm{Al}$ and $\mathrm{Zr} / \mathrm{Al}$ ratios, and the grain size distribution (Fig. 4). These parameters have been studied in TC484, a core that is longer than BC484 and, therefore, allows a better comparison between the phosphorite layer and the sediment beneath it. A comparison between BC484 and TC484 of the $\mathrm{C}_{\text {org }}$ and $\mathrm{P}_{\text {tot }}$ profiles revealed an offset of $10 \mathrm{~cm}$. Probably, the top $10 \mathrm{~cm}$ of TC484 were lost during core recovery. It is noteworthy that the high $\mathrm{P}$ concentration is still present in TC484, despite the distance of $4 \mathrm{~km}$ to BC484. Obviously, the processes leading to phosphorite formation are not very localised. The $\mathrm{C}_{\text {org }} / \mathrm{N}_{\text {tot }}$ ratio (\% w/w) in the upper centimetre of TC484 is 8.6, which falls in the range of 7-9 observed in the top sediments on the Oman Margin (Pedersen et al., 1992). These low $\mathrm{C}_{\text {org }} / \mathrm{N}_{\text {tot }}$ ratios are common for many recent sediments that have not been subject to winnowing (e.g. Calvert et al., 1995; Van der Weijden et al., 1999). The $\mathrm{C}_{\text {org }} /$ $\mathrm{N}_{\text {tot }}$ ratio increases downcore to a constant value of 10 , which reflects the normal pattern of preferential nitrogen release relative to carbon during organic matter degradation. This suggests that the organic matter in the top of the sediment has not been extensively degraded and thus has not been subjected to intense winnowing. Winnowed material often consists of coarse-grained skeletal carbonate (foraminiferal oozes). O'Brien et al. (1990) found a close correlation between bottom water current velocity and the $\mathrm{CaCO}_{3}$ content of sediments on the East Australian continental margin. The $\mathrm{CaCO}_{3}$ concentrations in the entire tripcore fall within the range of $25-50 \mathrm{wt} \%$, observed for non-winnowed sediments on the Oman Margin (Shimmield et al., 1990). The Ca concentration in the phosphorus-rich layer is in fact lower than deeper in the sediment, indicating that the top is not winnowed. $\mathrm{Zr}$ and $\mathrm{Ti}$ are enriched in heavy minerals, and will be concentrated in the coarse fraction of the sediment. The rather constant values of these ratios in TC484 are another indication for the absence of active winnowing. Further evidence is provided by the mean grainsize of both the decarbonated fraction and the bulk sediment, which is also constant with depth. The high mean grainsize in this core is probably caused by the input of eolian material, since this site is in close proximity to the Arabian peninsula. We conclude that although located in an environment where physical concentration processes may occur, winnowing is not responsible for the high phosphorus concentrations in this sediment.

\subsubsection{Redeposition}

The continental slope of the Oman Margin is particularly steep (Prell and shipboard party of ODP Leg $117,1990)$ and, therefore, redeposition processes are likely to occur. Seismic data taken during the retrieval of the sediment cores show that BC484 and TC484 were taken in a small depression, containing a thick cover of sediments. This depression is probably one of the small intrashelf basins previously observed on the Oman Margin (Prell and shipboard party of ODP Leg 117, 1990; Shimmield et al., 1990), and could 
potentially have served as a trap for phosphorus-rich turbidites (Kolodny and Garrison, 1994). The calibrated ${ }^{14} \mathrm{C}$ ages for "clean" (i.e. un-coated) foraminifers indicate normal sedimentation for the last 13,000 yr (Table 3). The "clean" foraminifers from the top sediment (0-2 cm depth) are dated at $373 \mathrm{yr}$. Furthermore, the overall chemical composition of the sediment does not indicate any sharp, erosive boundaries or internal grading. The top $20 \mathrm{~cm}$ of the sediment is not homogenous in composition, as would be expected when it would have been deposited during one single redepositional event. The calibrated ${ }^{14} \mathrm{C}$ ages of the coated foraminifers and phosphatised pellets in the top 0-2 cm, conversely, are older than the "clean" foraminifers (Table 3), suggesting a nonrecent origin of these particles. This age difference is also observed deeper in the sediment. It is possible that during the early diagenetic precipitation of francolite part of the carbonate incorporated into the apatite is supplied by diffusion of "older" $\mathrm{HCO}_{3}^{-}$ from a deeper level in the sediment. Phosphatisation of calcitic particles would thus lead to an increase in their ${ }^{14} \mathrm{C}$ ages, which would explain why the phosphatised nodules are older than the coated foraminifers. Age calculations, in which the chemical composition of the samples is used to determine the individual age of the apatite and carbonate fraction, indicate, however, that this process can only partly explain the older ages: depending on the age of apatite coatings, the carbonate of the coated foraminifers must have been formed between 4 and $10 \mathrm{kyr} \mathrm{BP}$, and thus is not of a recent origin. A difference in calibrated ${ }^{14} \mathrm{C}$ ages for phosphatised particles and pure calcite at equal sediment depths was also reported for a modern phosphorite deposit on the Peru Margin (Burnett et al., 1988), which was explained by the mixing of older pellets from a deeper level with recently formed pellets. This is not plausible for BC484, as no high $\mathrm{P}$ concentrations are present deeper in the sediment. The calibrated ${ }^{14} \mathrm{C}$ ages are therefore best explained by lateral transport of the phosphatised foraminifers to the location of NIOP station 484.

We argue that the phosphatised material from in BC484 originates from two different sources. The first source is probably derived from the continental shelf or upper slope of Oman. Phosphorites consisting of phosphatised algal pellets, corals and pelletal limestones were formed on the western continental shelf and upper shelf of India during the early Holocene (Rao and Lamboy, 1996), which has been related to the intensification of the SW monsoon. Formation of Holocene phosphorites on the continental shelf of Oman has not been reported, but similarities in oceanic and climatic conditions between the two margins makes their occurrence plausible. The phosphatised particles may have been transported downslope to be deposited in the small depression where BC484 was retrieved. The age difference between "clean" and "coated" foraminifers observed at both 2 and $24.5 \mathrm{~cm}$ depth implies that the downslope transport of phosphatised particles was a gradual process. The spherical and rounded pellets could be an indication for reworking (Glenn et al., 1994), but their smooth surfaces could also be explained by an external development of microbes around the grains (Garrison and Kastner, 1990).

A second, present-day period of in situ phosphogenesis is indicated by the porewater profiles of phosphate and fluoride. Assuming steady state, the downward fluoride $\left(J_{\mathrm{F}}\right)$ flux (Table 6) can be converted into a solid-phase authigenic P concentration, using the mass accumulation rate and a $\mathrm{P} / \mathrm{F}$ ratio of 2.4. This results in a $P$ concentration of $21.000 \mathrm{ppm}$. The downward flux of fluoride may thus account for the high solid-phase $\mathrm{P}$ content in the top of BC484. In situ phosphogenesis, therefore, seems more important than the contribution of reworked phosphogenetic material. The calculated downward fluxes of phosphate and fluoride for BC484 (Table 6) are similar to estimates for modern phosphorite formation (Froelich et al., 1988; Schuffert et al., 1994). We conclude that the high phosphorus content is the result of both redeposition of phosphatised particles and high rates of in situ phosphogenesis. The phosphorite in the top of $\mathrm{BC} 484$ can therefore be classified as a combination of an allochthonous and a pristine phosphate (Föllmi, 1996).

To the best of our knowledge, this is the first report of Holocene phosphorite formation on the Oman Margin. During ODP leg 117, old phosphorites were found predominantly on the upper continental slope (site 726, $330 \mathrm{~m}$ water depth) located in the proximity of BC484, which were deposited during the Miocene till the Early Pleistocene (Rao and Lamboy, 1995). These phosphorite deposits consist of coprolites, 
faecal pellets, spherical and coated grains, micronodules, foraminifer infillings and fish bone fragments, which is similar to the phosphorite particle composition in BC484. A comparison with the Peru Margin showed, however, that the number and thickness of Oman phosphorites is far less. Rao and Lamboy (1995) attributed this to: (1) a less reactive nature of the organic matter; (2) high porewater alkalinity of the carbonate-rich sediments; (3) high sedimentation rates which inhibit hardground conditions; and (4) periods of a less pronounced OMZ.

The high present-day rates of phosphogenesis in BC484 can be attributed to three processes. First of all, the reworked coated foraminifers and phosphatised pellets probably provide reactive surface areas, which facilitate the precipitation of francolite. This explains why the "clean", non-transported foraminifers have no francolite overgrowths. Secondly, the higher primary production on the Oman Margin in the Holocene (Naidu and Malmgren, 1996) has increased the flux of reactive $\mathrm{P}$ to the seafloor and, thus, has promoted higher rates of phosphogenesis. Part of the high concentration of fish debris in the top of $\mathrm{BC} 484$ may originate from transport from shelf sediments, supplying an additional source of reactive $\mathrm{P}$. Thirdly, results from piston core 484, taken at the same location as TC484, show that sedimentation rates decreased sharply from the last glacial (ca. $30-50 \mathrm{~cm} \mathrm{kyr}^{-1}$ ), into the Holocene $\left(5.6 \mathrm{~cm} \mathrm{kyr}^{-1}\right)$. The Holocene drop in sedimentation rate could have contributed to the higher $\mathrm{P}$ content, because lower sediment accumulation rates will: (a) decrease the dilution of the precipitated francolite by other sediment components (Froelich et al., 1988); (b) increase the residence time of the sediment in the zone of active precipitation (at greater depth precipitation will be prohibited by a high alkalinity and lower porewater F concentrations); and (c) concentrate the source for phosphate regeneration (organic matter, fish debris), and, therefore, promote the build-up of phosphate in the porewater.

The fact that until now Holocene phosphorites have not been reported for the northern Arabian Sea may indicate that they are less common than in other upwelling areas. The narrow slope and shelf of the Oman Margin may limit phosphorite formation to a small area (i.e. at the intersection with the OMZ). Furthermore, high rates of phosphogenesis may be restricted to the small intrashelf basins, where the sediment is protected from the effects of winnowing. On the Peru Margin phosphorites were found to be irregularly distributed over the seafloor (Froelich et al., 1988; Baker and Burnett, 1988). As a consequence, recent phosphorite formation on the Oman Margin may have remained unobserved thus far. More detailed sampling is necessary to determine the extent of Holocene phosphorite formation on the Oman Margin.

\section{Conclusions}

Porewater and solid-phase $\mathrm{P}$ speciation results indicate that phosphogenesis is occurring in the surface sediments located within the OMZ of the Arabian Sea. The precipitation of a precursor precedes francolite formation in the sediments on the Karachi Margin. The highest rate of francolite formation was observed in a boxcore taken on the Oman Margin where it contributes to the formation of a Holocene phosphorite deposit. This observation contrasts with previous reports of only old phosphorites in this area. Application of a diagenetic $\mathrm{P}$ model revealed that phosphogenesis on the Pakistan Margin is induced by high rate of organic matter degradation and, probably, fish debris dissolution. Early diagenetic iron cycling does not significantly affect sedimentary $\mathrm{P}$ cycling in these environments. The occurrence of some bioturbation is essential to initiate phosphogenesis in these sediments. This implies that dysoxic rather than fully anoxic bottom waters may be more effective in promoting early diagenetic phosphogenesis.

Phosphorites are presently forming on the Oman Margin as the result of: (a) deposition of older, reworked material from the shelf, which has undergone an earlier phase of phosphogenesis; (b) a high Holocene input of reactive $\mathrm{P}$ (fish debris and degradable organic matter); (c) a relatively low sedimentation rate; and (d) absence of winnowing at this location, which would increase the permeability and enhance the degradation of organic material and the dissolution of fish debris.

\section{Acknowledgements}

The chief scientists on the NIOP cruises during the 
1992-1993 Netherlands Indian Ocean Programme were W.J.M. van der Linden and C.H. van der Weijden. H. de Waard, A.F.M. de Jong and G. Nobbe are thanked for their contribution to the laboratory analyses, and G.J. van het Veld and G. Ittman for processing the micropaleontological samples. H.F. Passier is acknowledged for providing the porewater data of BC484. Critical reviews by C.H. van der Weijden, G.J. Reichart, K.B. Föllmi and J.D. Schuffert significantly improved this manuscript. This research was funded by the Netherlands Organisation for Scientific Research (NWO). This is publication 20000701 of the Netherlands School of Sedimentary Geology.

\section{Appendix A}

Porewater profiles have been used to estimate the downward fluxes of fluoride and phosphate (francolite precipitation rates), assuming steady state and constant bulk sediment compositions. Diffusive porewater fluxes $(J)$ have been calculated with (Berner, 1980):

$J=-\varphi D_{\mathrm{s}}(\mathrm{d} C / \mathrm{d} z)$

in which $\phi$ is the mean porosity, $D_{\mathrm{s}}$ the whole sediment diffusion coefficient for phosphate and fluoride and $\mathrm{d} C / \mathrm{d} z$ the linear concentration gradient at depth $z$. Whole sediment diffusion coefficients $\left(D_{\mathrm{s}}\right)\left(\mathrm{cm}^{2} \mathrm{~s}^{-1}\right)$ can be expressed by

$D_{\mathrm{s}}=D^{*} / \varphi F$

where $D^{*}$ is the diffusion coefficient in seawater and $F$ is the formation factor. Diffusion coefficients $\left(7.34 \times 10^{-6}\right.$ and $14.6 \times 10^{-6} \mathrm{~cm}^{2} \mathrm{~s}^{-1}$ for $F^{-}$at $25^{\circ} \mathrm{C}$ ) were corrected for the in situ bottom water temperature with the Stokes-Einstein relation ( $\mathrm{Li}$ and Gregory, 1974). The formation factors were estimated with the equation (Manheim and Waterman, 1974):

$\log F=0.110-1.80 \log \varphi$

The downward fluxes were calculated from the average fluoride and phosphate gradients (for BC484 the phosphate/fluoride gradient was taken at a specific depth). The fluoride flux $\left(J_{\mathrm{F}}\right)$ was multiplied with the molar $\mathrm{P} / \mathrm{F}$ ratio of authigenic francolite $(2.4$; as measured in the solvent of step 4 of the sequential extraction in $\mathrm{BC} 484)$ to obtain $\left(J_{\mathrm{P}(\mathrm{F})}\right)$, which allows a direct comparison with the downward phosphate flux.

\section{References}

Aspila, K.I., Agemain, H., Chau, A.S.Y., 1976. A semi-automated method for the determination of inorganic, organic and total phosphate in sediments. Analyst 101, 187-197.

Atlas, E., Pytkowicz, R.M., 1977. Solubility behavior of apatites in seawater. Limnol. Oceanogr. 22, 290-300.

Baker, K.B., Burnett, W.C., 1988. Distribution, texture and composition of modern phosphate pellets in Peru shelf muds. Mar. Geol. 80, 195-213.

Bard, E., Hamelin, B., Fairbanks, R.G., Zindler, A., 1990. Calibration of the ${ }^{14} \mathrm{C}$ timescale over the past 30,000 years using mass spectrometric U-Th ages from Barbados corals. Nature 345, 405-410.

Berger, W.H., Herguera, J.C., 1992. Reading the sedimentary record of the ocean's productivity. In: Falkowski, P.G., Woodhead, A.D. (Eds.). Primary productivity and biogeochemical cycles in the sea, Plenum Press, New York, pp. 455-486.

Berner, R.A., 1980. Early Diagenesis: a theoretical approach, Princeton University Press, Princeton, NJ (241 pp.).

Boudreau, B.P., 1994. Is burial velocity a master variable for bioturbation? Geochim. Cosmochim. Acta 58, 1243-1249.

Boudreau, B.P., 1997. Diagenetic models and their implementation, Springer, Berlin (316 pp.).

Burnett, W.C., Beers, M.J., Roe, K.K., 1982. Growth rates of phosphate nodules from the continental margin off Peru. Science 215, 1616-1618.

Burnett, W.C., Roe, K.K., Piper, D.Z., 1983. Upwelling and phosphorite formation in the ocean. In: Suess, E., Thiede, J. (Eds.). Coastal Upwelling, its sediment record, part A, Plenum Press, New York, pp. 377-397.

Burnett, W.C., Baker, K.B., Chin, P.A., McCabe, W., Ditchburn, R., 1988. Uranium-series and AMS ${ }^{14} \mathrm{C}$ studies of modern phosphatic pellets from Peru shelf muds. Mar. Geol 80, 215-230.

Calvert, S.E., Pedersen, T.F., Naidu, P.D., von Stackelberg, U., 1995. On the organic carbon maximum on the continental slope of the eastern Arabian Sea. J. Mar. Res. 53, 269-296.

Chien, S.-S., 1972. Ion-activity products of some apatite minerals. $\mathrm{PhD}$ thesis, Iowa State University. $144 \mathrm{pp}$.

Cook, P.J., 1984. Spatial and temporal controls on the formation of phosphate deposits - a review. In: Nriagu, J.O., Moore, P.B. (Eds.). Phosphate minerals, Springer, Berlin, pp. 242-272.

De Lange, G.J., 1992a. Shipboard routine and pressure-filtration system for pore-water extraction from suboxic sediments. Mar. Geol. 109, 77-81.

De Lange, G.J., 1992b. Distribution of various extracted phosphorus compounds in the interbedded turbiditic/pelagic sediments of the Madeira Abyssal Plain, eastern North Atlantic. Mar. Geol. 109, 115-139.

Filippelli, G.M., Delaney, M.L., 1994. Phosphogenesis and the 
controls on phosphorus accumulation in continental margin sediments. In: Proceedings of the 29th International Geological Congress, Part C. pp. 189-204.

Filippelli, G.M., Delaney, M.L., 1996. Phosphorus geochemistry of equatorial Pacific sediments. Geochim. Cosmochim. Acta 60, 1479-1495.

Föllmi, K.B., 1996. The phosphorus cycle, phosphogenesis and marine phosphate-rich deposits. Earth Sci. Rev. 40, 55-124.

Froelich, P.N., Kim, K.H., Jahnke, R., Burnett, W.C., Soutar, A., Deakin, M., 1983. Pore water fluoride in Peru continental margin sediments: uptake from seawater. Geochim. Cosmochim. Acta 47, 1605-1612.

Froelich, P.N., Arthur, M.A., Burnett, W.C., Deakin, M., Hensley, V., Jahnke, R., Kaul, L., Kim, K.-H., Roe, K., Soutar, A., Vathakanon, C., 1988. Early diagenesis of organic matter in Peru continental margin sediments: phosphorite precipitation. Mar. Geol. 80, 309-343.

Garrison, R.E., Kastner, M., 1990. Phosphatic sediments and rocks recovered from the Peru margin during ODP Leg 112. Proc. ODP Sci. Results 112, 111-134.

Gieskes, J.M., 1973. Interstitual water studies leg15 - alkalinity, $\mathrm{pH}, \mathrm{Mg}, \mathrm{Ca}, \mathrm{Si}, \mathrm{PO}_{4}$ and $\mathrm{NH}_{4}$. Init. Rep. DSDP, US Gov. Print. Office, Washington, vol. 20. pp. 813-829.

Glenn, C.R., Arthur, M.A., 1988. Petrology and major element geochemistry of Peru Margin phosphorites and associated diagenetic minerals: authigenesis in modern organic-rich sediments. Mar. Geol. 80, 231-267.

Glenn, C.R., Föllmi, K.B., Riggs, S.R., Baturin, G.N., Grimm, K.A., Trappe, J., Abed, A.M., Galli-Olivier, C., Garrison, R.E., Ilyin, A.V., Jehl, C., Rohrlich, V., Sadaqah, R.M.Y., Schidlowski, M., Sheldon, R.E., Siegmund, H., 1994. Phosphorus and phosphorites: sedimentology and environments of formation. Eclogae Geol. Helv. 87, 747-788.

Heggie, D.T., Skyring, G.W., O’Brien, G.W., Reimers, C.E., Herczeg, A., Moriarty, D.J.W., Burnett, W.C., Milnes, A.R., 1990. Organic carbon and modern phosphorite formation on the East Australian continental margin: an overview. Geol. Soc. Spec. Publ. 52, 87-117.

Ingall, E.D., Jahnke, R.A., 1994. Evidence for enhanced phosphorus regeneration from marine sediments overlain by oxygendepleted waters. Geochim. Cosmochim. Acta 58, 2571-2575.

Ingall, E.D., Bustin, R.M., Van Cappellen, P., 1993. Influence of water column anoxia on the burial and preservation of carbon and phosphorus in marine shales. Geochim. Cosmochim. Acta 57, 303-316.

Jahnke, R.A., Emerson, S.R., Roe, K.V., Burnett, W.C., 1983. The present day formation of apatite in Mexican continental margin sediments. Geochim. Cosmochim. Acta 47, 259-266.

Jannink, N.T., Zachariasse, W.J., Van der Zwaan, G.J., 1998. Living (Rose Bengal stained) benthic foraminifera from the Pakistan continental margin (northern Arabian Sea). Deep-Sea Res. 45, $1483-1513$.

Jarvis, I., Burnett, W.C., Nathan, Y., Almbaydin, F.S.M., Attia, A.K.M., Castro, L.N., Flicoteaux, R., Hilmy, M.E., Husain, V., Qutawnah, A.A., Serjani, A., Zanin, Y.N., 1994. Phosphorite geochemistry: state-of-the-art and environmental concerns. Eclogae Geol. Helv. 87, 643-700.
Kolodny, Y., 1981. In: Emiliani, C. (Ed.). Phosphorites, The Sea, Vol. 7. Wiley, New York, pp. 981-1023.

Kolodny, Y., Garrison, R.E., 1994. Sedimentation and diagenesis in paleo-upwelling zones of epeiric sea and basinal settings: a comparison of the Cretaceous Mishash Formation of Israel and the Miocene Monterey Formation of California. In: Iijima, A., Abed, A.M., Garrison, R.E. (Eds.), Siliceous Phosphatic and Glauconitic Sediments of the Tertiary and Mesozoic. In: Proceedings of the 29th International Geological Congress, Part C, VSP, Utrecht. pp. 133-158.

Krajewski, K.P., Van Cappellen, P., Trichet, J., Kuhn, O., Lucas, J., Martin-Algarra, A., Prévôt, L., Tewari, V.C., Gaspar, L., Knight, R.I., Lamboy, M., 1994. Biological processes and apatite formation in sedimentary environments. Eclogae Geol. Helv. 87, 701-745.

Li, Y.L., Gregory, S., 1974. Diffusion of ions in seawater and in deep-sea sediments. Geochim. Cosmochim. Acta 38, 703-714.

Lord III, C.J., 1982. A selective and precise method for pyrite determination in sedimentary materials. J. Sed. Petr. 52, 664666.

Louchouarn, P., Lucotte, M., Duchemin, E., de Vernal, A., 1997. Early diagenetic processes in recent sediments of the Gulf of St-Lawrence: phosphorus, carbon and iron burial rates. Mar. Geol. 139, 181-200.

Lucotte, M., Mucci, A., Hillaire-Marcel, C., Tran, S., 1994. Early diagenetic processes in deep Labrador Sea sediments: reactive and nonreactive iron and phosphorus. Can. J. Earth Sci. 31, 1427.

Manheim, F.T., Waterman, L.S., 1974. Diffusimitry (diffusion constant estimation) on sediment cores by resistivity probe. Initial reports of the Ocean Drilling project, vol. 22. pp. 663670.

McClellan, G.H., 1980. Mineralogy of carbonate fluorapatites. J. ooGeol. Soc. London 137, 675-681.

Naidu, P.D., Malmgren, B.A., 1996. A high-resolution record of Late Quaternary upwelling along the Oman Margin, Arabian Sea based on planktonic foraminifera. Paleoceanography 11, 129-140.

O’Brien, G.W., Milnes, A.R., Veeh, H.H., Heggie, D.T., Riggs, S.R., Cullen, D.J., Marshall, J.F., Cook, P.J., 1990. Sedimentation dynamics and redox iron-cycling: controlling factors for the apatite-glauconite association on the East Australian continental margin. Geol. Soci. Spec. Publ. 52, 61-86.

Pedersen, T.F., Shimmield, G.B., Price, N.B., 1992. Lack of enhanced preservation of organic matter in sediments under the oxygen minimum zone on the Oman Margin. Geochim. Cosmochim. Acta 56, 545-551.

W.L. Prell and shipboard party of ODP Leg 117., 1990. Neogene tectonics and sedimentation of the SE Oman continental margin: results from ODP Leg 117. Geol. Soc. Spec. Publ. 49, 745-758.

Price, N.B., Calvert, S.E., 1978. The geochemistry of phosphorites from the Namibian shelf. Chem. Geol. 23, 151-170.

Qasim, S.Z., 1982. Oceanography of the northern Arabian Sea. Deep-Sea Res. 29, 1041-1068.

Rao, V.P., Lamboy, M., 1995. Phosphorites from the Oman Margin. Oceanol. Acta 18, 289-307.

Rao, V.P., Lamboy, M., 1996. Genesis of apatite in the phospha- 
tized limestones of the western continental shelf of India. Mar. Geol. 136, 41-53.

Reimers, C.E., Ruttenberg, K.C., Canfield, D.E., Christiansen, M.B., Martin, J.B., 1996. Porewater $\mathrm{pH}$ and authigenic phases formed in the uppermost sediments of the Santa Barbara Basin. Geochim. Cosmochim. Acta 60, 4037-4057.

Ruttenberg, K.C., 1992. Development of a sequential extraction method for different forms of phosphorus in marine sediments. Limnol. Oceanogr. 37, 1460-1482.

Ruttenberg, K.C., Berner, R.A., 1993. Authigenic apatite formation and burial in sediments from non-upwelling, continental margin environments. Geochim. Cosmochim. Acta 57, 991-1007.

Schenau, S.J., 1999. Cycling of phosphorus and manganese in the Arabian Sea during the Late Quaternary. Geologica Ultraiectina $182, \mathrm{PhD}$ thesis.

Schenau, S.J., De Lange, G.J., 2000. A novel chemical method to quantify fish debris in marine sediments. Limnol. Oceanogr. 45, 963-971.

Schuffert, J.D., Jahnke, R.A., Kastner, M., Leather, J., Sturz, A., Wing, M.R., 1994. Rates of formation of modern phosphorite off western Mexico. Geochim. Cosmochim. Acta 58, 5001-5010.

Schuffert, J.D., Kastner, M., Jahnke, R.A., 1998. Carbon and phosphorus burial associated with modern phosphorite formation. Mar. Geol. 146, 21-31.

Schulz, H., von Rad, U., von Stackelberg, U., 1996. Laminated sediments from the oxygen-minimum zone of the northeastern Arabian Sea. Geol. Soc. Spec. Publ. 116, 185-207.

Shimmield, G.B., Price, N.B., Pedersen, T.F., 1990. The influence of hydrography, bathymetry and productivity on sediment type and composition of the Oman Margin and in the Northwest Arabian Sea. Geol. Soc. Spec. Publ. 49, 759-769.

Sirocko, F., Sarnthein, M., Erlenkeusers, H., Lange, H., Arnold, M., Duplessy, J.C., 1993. Century-scale events in monsoonal climate over the past 24,000 years. Nature 364, 322-324.

Slomp, C.P., Epping, E.H.G., Helder, W., Van Raaphorst, W., 1996. A key role for iron-bound phosphorus in authigenic apatite formation in North Atlantic continental platform sediments. J. Mar. Res. 54, 1179-1205.

Slomp, C.P., Malschaert, J.F.P., Van Raaphorst, W., 1998. The role of adsorption in sediment-water exchange of phosphate in North Sea continental margin sediments. Limnol. Oceanogr. 43, 832 846.

Smith, C.R., Levin, L.A., Hoover, D.J., McMurtry, G., Gage, J.D., 2000. Variations in bioturbation across the oxygen minimum zone in the northwest Arabian Sea. Deep-Sea Res. II 47, $227-$ 257.

Solarzano, L., 1969. Determination of ammonia in natural water by phenol-hypochlorite method. Limnol. Oceanogr. 14, 799-801.

Strickland, J.D.H., Parsons, T.R., 1968. A practical handbook of seawater analysis. Fish. Board Can. Bull., vol. 167. 311 pp.

Stuiver, M., Reimer, P.J., Bard, E., Beck, J.W., Burr, G.S., Hughen, K.A., Kromer, B., McCormac, F.G., Plicht, J.v.d., Spurk, M., 1998. INTCAL98 Radiocarbon age calibration, 24,000-0 cal BP. Radiocarbon 40, 1041-1083.

Suess, E., 1981. Phosphate regeneration from sediments of the Peru continental margin by dissolution of fish debris. Geochim. Cosmochim. Acta 45, 577-588.

Sundby, B., Gobeil, C., Silverberg, N., Mucci, A., 1992. The phosphorus cycle in coastal marine sediments. Limnol. Oceanogr. 37, 1129-1145.

Thomson, J., Calvert, S.E., Mukherjee, S., Burnett, W.C., Bremner, J.M., 1984. Further studies of the nature, composition and ages of contemporary phosphorite from the Namibian Shelf. Earth Planetary Sci. Lett. 69, 341-353.

Trappe, J., 1998. Phanerozoic phosphorite depositional systems, a dynamic model for a sedimentary resource system, , Lecture Notes in Earth Sciences, vol. 76, Springer, Berlin (316 pp.).

Van Bennekom, J., Hiehle, M., 1994. In: van der Linden, W.J.M., van der Weijden, C.H. (Eds.). CTD operations and calibrations during legs D1, D2 and D3 of the Netherlands Indian Ocean Programme, Geological study of the Arabian Sea, vol. 3. National Museum of Natural History, Leiden, pp. 37-65.

Van Cappellen, P., Berner, R.A., 1988. A mathematical model for the early diagenesis of phosphorus and fluorine in marine sediments: apatite precipitation. Am. J. Sci. 288, 289-333.

Van Cappellen, P., Berner, R.A., 1991. Fluorapatite crystal growth from modified seawater solutions. Geochim. Cosmochim. Acta $55,1219-1234$.

Van der Weijden, C.H., Reichart, G.J., Visser, H.J., 1999. Enhanced preservation of organic matter in sediments deposited within the oxygen minimum zone in the northeastern Arabian Sea. DeepSea Res. 46, 807-830.

Von Rad, U., Schaaf, M., Michels, K.H., Schulz, H., Berger, W.H., Sirocko, F., 1999. A 5000-yr record of climate change in varved sediments from the oxygen minimum zone off Pakistan, northeastern Arabian Sea. Q. Res. 51, 39-53.

Williams, L.A., Reimers, C.E., 1983. Role of bacterial mats in oxygen-deficient marine basins and coastal upwelling regimes: preliminary report. Geology 11, 267-269. 